\title{
Estimation of microbial protein supply in ruminant animals based on renal and mammary purine metabolite excretion. A review
}

\author{
K.J. Shingfield \\ Agricultural Research Centre of Finland, Animal Production Research \\ FIN-31600 Jokioinen, Finland
}

(Received 3 March 2000; accepted 8 May 2000)

\begin{abstract}
The potential of mammary and renal purine metabolite excretion as a technique for the assessment of microbial protein supply in ruminant animals is reviewed. Data reported in the literature tends to support the validity of the assumptions of the technique that purines entering the duodenum are essentially microbial in origin and that following metabolism, purine catabolites (collectively allantoin, hypoxanthine, uric acid and xanthine) are quantitatively recovered in urine. The most convincing experimental evidence suggests that secretion of purine metabolites in milk is of little value for the assessment of microbial protein supply duc a mutual correlation with milk yield. In contrast. use of urinary purine metabolite excretion does appear to provide estimates of microbial protein supply that, are in general, consistent with values derived using standard in vivo procedures. However, the accuracy of this approach is largely dependent on obtaining representative sampies of rumen microbes and the ability to account for variations in non-renal excretion and endogenous purine losses. In conclusion, urinary purine metabolite excretion appears to represent a valid noninvasive procedure to assess relative differences, rather than quantitative estimates of microbial protein supply in ruminant animals.
\end{abstract}

KEV WORDS: purine metabolites, microbial protein, nucleic acids, ruminants, urine, milk

\section{INTRODUCTION}

Over recent years considerable emphasis has been placed on the protein feeding of ruminant animals, since dietary crude protein is often the most cxpensive feed ingredient, and feeding excessive amounts of protein can depress reproductive efficiency (Ferguson and Chalupa, 1989), increase energy requirements (Old- 
ham, 1984) and elevate environmental nitrogen (N) emissions (Broderick and Clayton, 1997). In ruminant animals the quantity of amino acids available for absorption is determined by the quantity of microbes synthesized in the rumen, the amount of undegraded dietary protein and to a lesser extent, by endogenous protein reaching the duodenum (Satter, 1986). On most diets, microbial protein (MP) is the major component of duodenal protein and is thought to account for proportionately between 0.42 and 0.93 of the total protein flux entering the small intestine (Stern, 1986). Since prediction of MP supply is central to accurate protein feeding, errors in its prediction can lead to an inefficient utilization of dietary protein.

Traditionally, apparently digested $\mathrm{CP}$ ( $\mathrm{N}$ in feed minus $\mathrm{N}$ in facces) has been used to describe the availability of amino acids to the ruminant animal. During the last decade several new protein evaluation systems have been proposed (c.g., Institut National de la Recherche Agronomique (INRA), 1989; National Reseach Council (NRC). 1989; Agricultural and Food Rescarch Council (AFRC), 1992; Madsen et al., 1995; Tuori et al., 1998) in order to improve the accuracy of protein feeding to ruminant animals by accounting for both microbial and host tissue $\mathrm{N}$ metabolism. Despite differences in terminology and calculation methods, modern metabolizable protein evaluation systems are conceptually similar in that they all attempt to predict the quantity of amino acids available for absorption derived from both microbial and dietary protein escaping degradation in the rumen. All systems used for routine formulation of ruminant dicts use an empirical approach to predict MP based essentially on energy availability in the rumen assuming either a constant energetic efficiency of microbial protein synthesis (EMPS) (INRA, 1989; NRC, 1989; Madsen et al., 1995; Tuori et al., 1998) or that corrected for the effects of feeding level (AFRC, 1992).

However, although the yicld of MP synthesized in the rumen is generally considered to bc proportional to the energy available for fermentation, EMPS is subject to considerable variation. Based on 262 observations in sheep and cattle (a large proportion of which werc obtained from sheep at maintenance) and omitting estimates derived from experiments with rumen ammonia concentrations below $3.5 \mathrm{mmol} / \mathrm{l}$, Agricultural Reseach Council (1984) reported that EMPS varied between 19.3 and 44.7 (CV 39\%) g microbial-N/kg OM apparently digested in the rumen. Assuming that energy supply is the largest constraint on rumen MP synthesis, this variability can largely be attributed to differences in rumen outflow rates and the microbial maintenance coefficient (Dewhurst and Webster, 1992), and that introduced duc to errors associated with the quantification of MP supply. In addition to feeding level (Robinson et al., 1985; Chen et al., 1992a), differences in carbohydrate and $\mathrm{N}$ sources, defaunation, and dietary supplements of various agents such as ionophores and branch chain fatty acids may influence EMPS (refer to Sniffen and Robinson, 1987; Hoover and Stokes, 1991; Clark et al., 1992; Chamberlain and Choung, 1995). Consequently, due to the influence of these factors and 
the inadequacies of techniques used to determine the rate and extent of OM fermentation in the rumen (Dewburst et al., 1995) none of the modern protein cvaluation systems can provide an accurate prediction of MP supply for all animals and feeding situations.

Dewhurst et al. (1996) recently highlighted the requirement for an on-farm diagnostic marker of MP supply in order to improve the efficiency of dietary N utilization in ruminant animals. Standard in vivo procedures used to assess MP supply are unsuitable for this purpose, and therefore use of purine metabolite $\mathrm{cx}$ cretion considered to reflect rumen MP synthesis could have considerable potential since it is non-invasive. Use of the technique assumes that, purines entering the duodenum are essentially microbial in origin and that the end products of purine metabolism are quantitatively recovered in urine or milk. The aim of the current paper is to review purine metabolism in ruminant animals and provide a critical evaluation of the validity of the assumptions and potential sources of error for the estimation of MP supply based on purine metabolite excretion.

\section{QUANTIFICATION OF MICROBIAL PROTEIN SUPPLY}

\section{Microbial marker methods}

Standard in vivo procedures used for estimating MP supply are based on the use of internal or external microbial markers in conjunction with measurements of duodenal digesta flow, assessed either directly using a T-type duodenal cannula or estimated using indigestible markers. Internal markers include intergral structural components such as 2,6-diaminopimelic acid (DAPA) in bactcrial or 2-aminoethylphosphonic acid (AEPA) in protozoal cells or intra-cellular components such as RNA, DNA or individual pyrimidine and purine bases. External marker techniques are based on cellular incorporation of radio-isotopes (c.g. ${ }^{35} \mathrm{~S},{ }^{15} \mathrm{~N},{ }^{32} \mathrm{P}$ and ${ }^{3} \mathrm{H}$ ) to label microbial cells. Despite a wide choice of markers the principle is the same for all methods, in that the ratio of marker: $\mathrm{N}$ concentrations in rumen microbes is compared with that in duodenal digesta to calculate the proportion of duodenal $\mathrm{N}$ of microbial origin.

The merits and demerits of individual microbial markers have been documented (Stern and Hoover, 1979; Broderick and Merchen, 1992) and therefore considerations and concerns of traditional marker methods are only discussed in brief. Irrespective of type, an ideal microbial marker should be unique to microorganisms, not absorbed, biologically stable, easily measured, present at a constant ratio in rumen bacteria, protozoa and fungi, and between different stages of microbial growth (Horigane and Horiguchi, 1990). However, none of the current marker techniques satisfy all of these criteria because the ratio of marker: $\mathrm{N}$ concentra- 
tions are markedly different between rumen bacteria and protozoa, and in the case of internal markers also between fluid and particulate associated bacteria (Broderick and Merchen, 1992). Furthermore, additional concerns exist with the use of DAPA (Dufva et al., 1982; Rahnema and Theurer, 1986), AEPA (Ling and Buttery, 1978; Whitelaw et al., 1984; Horigane and Horiguchi, 1990) and nucleic acids (NA) (Smith et al., 1978; Ling and Buttery, 1978; McAllan, 1982) due to their presence in feedstuffs.

In an attempt to establish the most reliable method for assessing MP, a number of studies have evaluated several markers simultaneously (e.g. Ling and Buttery, 1978; Siddons et al., 1982; Whitelaw et al., 1984; Dawson et al., 1988; McAllan et al., 1988; Schönhusen et al., 1995; Robinson et al., 1996). Discrepancies between estimates of duodenal microbial-N flow based on different markers (Figure 1) indicate both a lack of precision and accuracy of these techniques, and therefore estimates can only be considered as relative and not absolute or reference measurements.

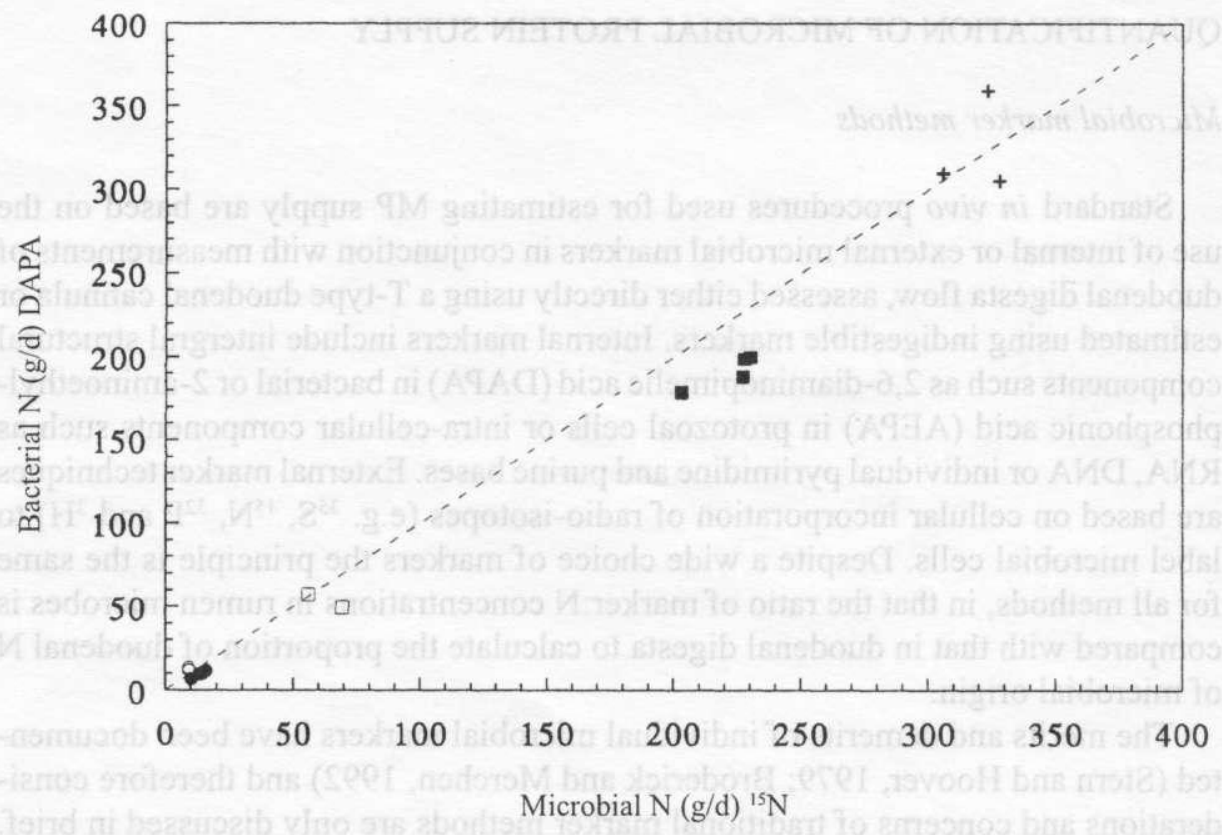

Figure 1. Comparison of markers to assess duodenal microbial (bacterial) nitrogen flow

a) Comparison of bacterial and microbial nitrogen flows $(\mathrm{g} / \mathrm{d})$ reported in the literature based on diaminopimelic acid (DAPA) and ${ }^{15} \mathrm{~N}$, respectively.

Data derived from Allam et al., 1982 (घ), Siddons et al., 1982 (O), Dawson et al., 1988 (口), Sadik et al., $1990(+)$ and Faichney et al., $1997(\bullet)$. Dotted line indicates $\mathrm{y}=\mathrm{x}$ 


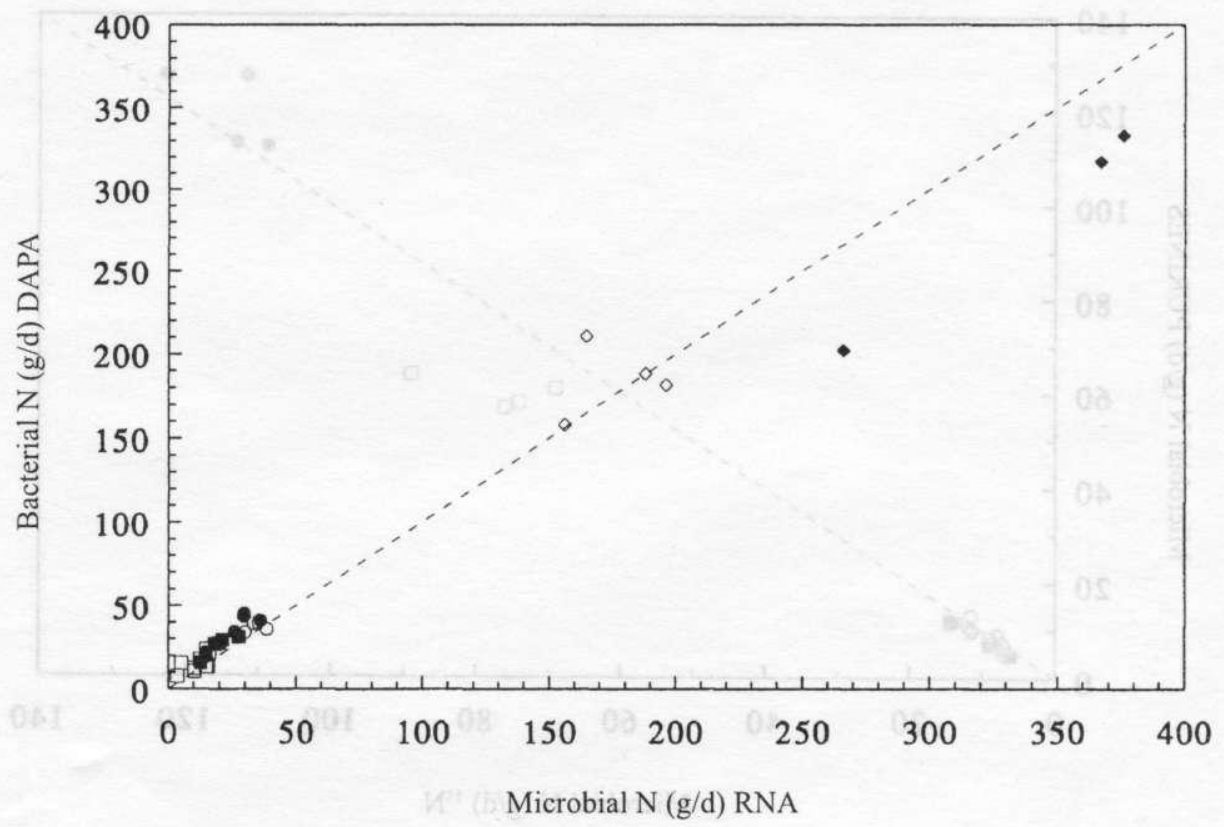

Figure 1. Comparison of markers to assess duodenal microbial (bacterial) nitrogen flow

b) Comparison of bacterial and microbial nitrogen flows $(\mathrm{g} / \mathrm{d})$ reported in the literature based on diaminopimelic acid (DAPA) and ribonucleic acid (RNA), respectively.

Data derived from Ling and Buttery, 1978 (口), Cockburn and Williams, 1984 (O), McAllan and Smith, 1984 (घ), McAllan et al., 1988 (•), Stokes et al., $1991(\bullet)$ and Robinson et al., $1996(0)$. Dotted line indicates $\mathrm{y}=\mathrm{x}$

It is also important to recognise the requirements of these methods for surgically modified experimental animals (rumen fistulas and post-rumen cannulas) and this has remained the largest drawback with existing microbial marker techniques. In addition to welfare concerns, and uncertainities as to how closely these animals reflect their physiologically normal counterparts, these procedures are unsuitable for large scale multi-factorial experiments. Furthermore, it could be argued that the inability to simultaneously assess the influence of a number factors on the efficiency of MP synthesis represents the largest constraint of current attempts to accurately predict MP supply.

Ruminant animals receive an abundant supply of potentially absorbable exogenous nucleic acids from microbes synthesized in the rumen. Following digestion and absorption from the small intestine, purine bases may enter catabolic pathways leading to formation of the purine metabolites (collectively allantoin, uric acid, xanthine and hypoxanthine) generally referred to as purine derivatives (PD). Early observations of Terrione and Mourot (1931) indicated a close correlation 


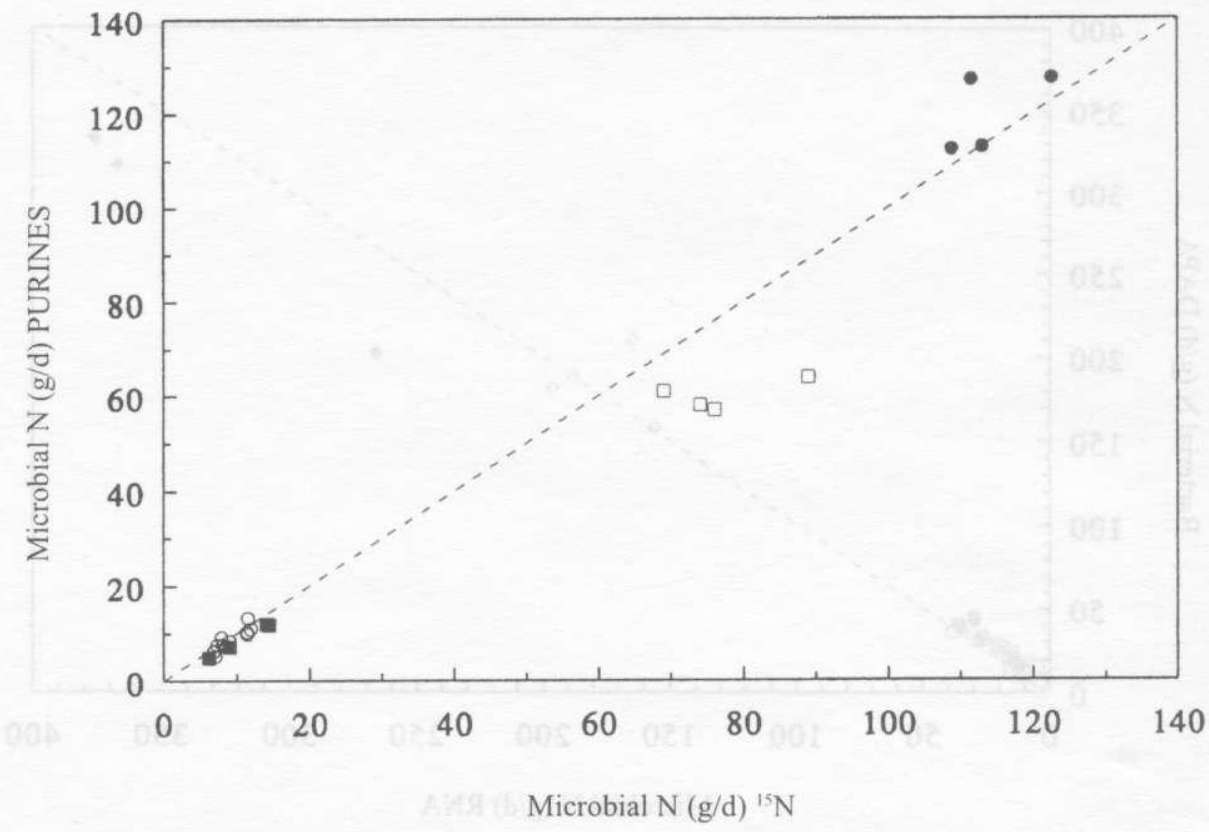

Figure 1. Comparison of markers to assess duodenal microbial (bacterial) nitrogen flow c) Comparison of microbial nitrogen flows $(\mathrm{g} / \mathrm{d})$ reported in the literature based on purines and ${ }^{15} \mathrm{~N}$. Data derived from Cecava et al., 1991 ( ), Vanhatalo, 1991 ( $\square)$, Pérez et al., 1996a (ש) and Pérez et al., 1997 (O). Dotted line indicates $y=x$

between urinary allantoin excretion, quantitatively the most important PD in ruminant species and protein intake in sheep. Morris and Ray (1939) demonstrated that urinary allantoin and uric acid excretion in sheep, goats and cows declined during a 7 day starvation period, suggesting an association with certain aspects of the diet. Further studies, reporting a close correlation between urinary allantoin excretion and rumen NA concentrations (Topps and Elliot, 1965; Mudgal and Taneja, 1977; Turchinski, 1980) and nutrient intake (e.g. Vercoe, 1976; Antoniewicz, 1983; Coto et al., 1984; Lindberg, 1985; Chen et al., 1992a; Giesecke et al., 1994) have provided further indirect evidence to support initial suggestions that urinary allantoin excretion could be used as an indicator of rumen MP production (Topps and Elliot, 1965; Ryś et al., 1975).

Use of PD excretion to assess MP supply assumes that purines entering the duodenum are essentially microbial in origin, limited variations in microbial purine content and digestibility, and that following metabolism, PDs are quantitatively recovered in urine or milk. However, there are a number of sources of error due to i) feed purines that escape rumen degradation, ii) variations in the purine content of rumen microbes, iii) variable partitioning of PDs between re- 
nal, mammary and enteric excretory routes and iv) excretion of PD due to endogenous purine metabolism.

\section{FATE OF NUCLEIC ACIDS IN THE RUMEN}

In common with marker methods based on RNA, or individual purine or pyrimidine bases, use of the PD technique is dependent on NA entering the duodenum being essentially microbial in origin. Ingested feedstuffs contain between 1-50 g $\mathrm{NA} / \mathrm{kg}$ DM (McAllan, 1982) and are the major source of NAs entering the rumen. Only small amounts of purines, uric acid and allantoin are present in forages (Ferguson and Terry, 1954). In addition to dietary NAs, endogenous NAs present in mucosal secretions and sloughed epithelia cells will also contribute to non-microbial NAs in the rumen, although in negligible amounts (McAllan, 1982).

Smith and McAllan (1970) reported that the RNA:DNA ratio in rumen fluid was similar to that in rumen bacteria and was independent of diet, indicating negligible amounts of dietary NA in rumen fluid. Other studics have demonstrated that the ratio of RNA:DNA in duodenal digesta is similar to the distinctive ratio of rumen bacteria, indicating that NAs entering the duodenum are essentially microbial in origin (Mugdal et al., 1978; McAllan, 1982), since dietary or infused exogenous NA entering the rumen are rapidly degraded into nucleotides, nuclcosides and free bases (McAllan and Smith, 1973a). End products of rumen NA digestion can subsequently be utilized by rumen microbes as a source of carbon and N (Belasco, 1954; Jurtshuk ct al., 1958) or directly incorporated as a NA precursor (Smith and Mathur, 1973).

While rumen bacteria can digest most purine and pyrimidine bases, Jurtshuk et al. (1958) reported that adenine was neither decarboxylated nor deaminated after in vitro incubation with a washed cell suspension of bovine rumen bacteria. Further studies have also demonstrated that adenine and xanthine, in particular, are partially resistant to degradation by rumen bacteria (McAllan and Smith, 1973b). With respect to PDs, allantoin (Bclasco, 1958), uric acid, and to a lesser extent hypoxanthine (Jurtshuk ct al., 1958) are extensively degraded in the rumen to acetic acid, carbon dioxide and ammonia. Urinary allantoin excretion has been shown to be independent of intra-ruminal infusions of allantoin in sheep and stecrs maintained by intra-gastric infusion (Chen et al., 1990b), indicating that even in the absence of a functional rumen microflora, allantoin is degraded, possibly due to the activities of the microbial population associated with the rumen epithelium.

Ruminal escape of dietary nucleic acids

In vivo studies using ${ }^{32} \mathrm{P}$ (Smith et al., 1978; John and Ulyatt, 1984) labelled NAs have indicated that non-microbial NA may contribute up to proportionately 
0.15 of duodenal purine flow. Koenig (cited by Schelling et al., 1982) reported that ruminal escape of NAs contained in lucerne hay was relatively minor, except immediately after feeding. Schelling and Byers (1984) evaluating the use of cytosine as a microbial marker, also noted that some dietary adenine can escape rumen degradation. Pérez et al. (1996b) attempted to assess the dictary contribution to the duodenal flow of purine bases based on in situ measurements of purine degradabilty corrected for microbial contamination. Bascd on this approach, it was estimated that for typical forage and cereal ingredients, proportionately betwcen 0.05 and 0.23 of purines contained in these feeds could potentially escape degradation in the rumen. In the case of fish meal and distillery by-products, this proportion was estimated to be between 0.20 and 0.40 . However, these values are subject to criticism due to the inherent deficiencies of the in situ technique to assess rumen degradability (Nocek, 1988; Michalet-Doreau and Ould-Bah, 1992), uncertainities concerning true rumen fractional outflow rates and dramatically lower microbial enzyme activitjes associated with incubated feed particles than rumen ingesta (Huhtanen et al., 1998). In an attempt to overcome the deficiencies of this approach, Calsamiglia et al. (1996) assessed degradation of purines contained in lucerne, maize, barley and a wide range of protein supplements using continous cultures of rumen microbes. Degradation of purines contained in most feeds was complete, with the exception of feather meal, and accounted for proportionately between 0.002 and 0.063 of purine flow in fermenter effluent. Examination of the most recent data reported in the literature suggests that ruminal escape of dietary NA represents a significant, but relatively minor source of purines entering the duodenum, the extent of which is potentially higher in animals fed diets containing relatively high proportions of rumen undegraded protein.

\section{PURINE CONTENT OF RUMEN MICROBES}

Usc of the PD technique is based on the assumption that the ratio of NA:N is constant in rumen bacteria and protozoa. Concentrations of NA and N (65-100 and 70-110 mg/g OM, respectively) in rumen bacteria (Smith and McAllan, 1974; Czerkawski, 1976; Storm and Orskov, 1983) tend to be marginally higher (50-90 and 40-90 $\mathrm{mg} / \mathrm{g} \mathrm{OM}$, respectively) than in rumen protozoa (Czerkawski, 1976; Olubobokun et al., 1988; Stokes et al., 1991; Martin et al., 1994; Robinson et al., 1996). Some studies have reported similar ratios of RNA:N (McAllan, 1982) or purine:N (Czerkawski, 1976; Volden et al., 1999) in rumen bacteria and protozoa, while other studies have indicated lower ratios in protozoa (Ling and Buttery, 1978; Arambel et al., 1982; Storm and Ørskov, 1983; Firkins et al., 1987; Stokes et al., 1991; Kanjanapruthipong and Leng, 1998). Protozoa can contribute to proportionately between 0.10 and 0.40 of MP supply (Harrison et al., 
1979; Steinhour et al., 1982; Punia et al., 1988, 1992; Punia and Leibholz, 1994; Faichney et al., 1997), and therefore lower purine: $N$ ratios identified in protozoa (Firkins et al., 1987; Kanjanapruthipong cited by Kanjanapruthipong and Leng, 1998), tentatively suggests that exclusive use of bacterial purine: $N$ ratios would underestimate microbial $\mathrm{N}$ flow.

Assumptions of a constant purine: $\mathrm{N}$ in rumen bacteria are also subject to criticism, since the RNA:N ratio of liquid associated bacteria (LAB) varies according to growth conditions in the rumen (Bergen et al., 1982; Bates and Bergen, 1984), feed intake (John, 1984), diet (Bates et al., 1985) and the techniques used to isolate rumen bacteria (Merry and McAllan, 1983). Furthermore, ratios of RNA: DNA (John, 1984) and RNA:N (Susmel ct al., 1993a) in LAB have been shown to vary diurnally. Craig et al. (1987b) also reported significant changes in the ratio of purine: $\mathrm{N}$ ratios in $\mathrm{LAB}$ and solid associated bacteria (SAB) during the feeding cycle of dairy cows, with the lowest ratios occuring immediately post-feeding. Subsequent studies have demonstrated that the extent of diurnal variations in the purine: $\mathrm{N}$ ratio of bacterial fractions is dependent on feeding frequency, being much lower in steers fed twice-hourly than twicc-daily (Cecava ct al., 1990).

In general, early studies reported in the literature have used LAB to discern fundamental information concerning rumen MP production, due to the technical difficulties of obtaining SAB (Olubobokun and Craig, 1990). This approach has been shown to be erroncous due to marked differences in the chemical composition of LAB and SAB (e.g. Merry and McAllan, 1983; Legay-Carmier and Bauchart, 1989; Volden and Harstad, 1998) and the significant and variable contribution of SAB to microbial N flow (Craig et al., 1987a; Pérez et al., 1998).

Clark et al. (1992) based on 50 observations reported large variations (CV 0.298) in the purine: $\mathrm{N}$ ratio of rumen bacteria. Some of this variation can be attributed to the techniques used to isolate rumen bacteria, since purine: $N$ ratios have consistently been shown to higher in LAB than SAB (e.g. Craig et al., 1987b; LegayCarmier and Bauchart, 1989; Cecava et al., 1990; Klusmeyer et al., 1991; MartínOrúc et al., 1998). A proportion of this variation is incvitably due to experimental diet (Pérez et al., 1997, 1998; Volden et al., 1999), but random expcrimental crrors associated with the determination of bacterial purine and $\mathrm{N}$ concentrations may also explain much of this variation. Purine concentrations of rumen microbes have traditionally been determined using a spectrophotometric method (Zinn and Owens, 1986) which can lead to erroneous estimates due to variable purine recoveries (Makkar and Becker, 1999; Obispo and Dehority, 1999). Furthermore, the purine:N ratios of pure cultures of rumen bacteria have recently been shown to be three-fold higher than corresponding values of mixed rumen bacteria, implying that determination of purine: $\mathrm{N}$ ratios in rumen bacteria may potentially be underestimated due to contamination by feed particles (Obispo and Dehority, 1999). 
The importance of obtaining representative values of purine: $\mathrm{N}$ ratio of rumen microbes is fundamental to the accuracy of estimates of MP supply based on the $\mathrm{PD}$ technique or derived using purines as a microbial marker. Ratios of purine: $\mathrm{N}$ in rumen bacteria are subject to considerable variation (Table 1), but the extent of which is due to real sources and that introduced as a result of sampling and analytical errors remains unclear. Chen et al. (1992a) proposed the use of a rumen microbe purine-N:N ratio of 0.116 , while Kanjanapruthipong, cited by Kanjanapruthipong and Leng (1998) reported an equivalent ratio of 0.0824 , indicating that

TABLE 1

Mean purine and nitrogen content and the ratio of purine: $N$ reported for rumen microbes

\begin{tabular}{lcccl}
\hline Microbial source & $\begin{array}{c}\text { Purine content } \\
\text { mg/g DM }\end{array}$ & $\begin{array}{c}\text { N content } \\
\mathrm{mg} / \mathrm{g} \mathrm{DM}\end{array}$ & $\begin{array}{c}\text { Purine:N } \\
\mathrm{g} / \mathrm{g}\end{array}$ & Reference \\
\hline LAB & 51.0 & 64.2 & 0.795 & Firkins et al. (1987) \\
SAB & 57.1 & 73.7 & 0.775 & \\
Protozoa & 25.7 & 58.6 & 0.438 & \\
LAB & 52.7 & 82.6 & 0.638 & Cecava et al. (1990) \\
SAB & 57.2 & 78.1 & 0.733 & \\
Mixed rumen bacteria & 72.8 & 77.1 & 0.944 & Clark et al. (1992) \\
Mixed rumen bacteria & $14.3^{1}$ & 82.9 & 0.173 & Calsamiglia et al. (1996) \\
Mixed rumen bacteria & 14.3 & 66.4 & 0.215 & Pćrez et al. (1996a) \\
LAB & $19.5^{2}$ & 67.5 & 0.289 & Pérez et al. (1997) \\
SAB & $16.2^{2}$ & 63.5 & 0.256 & \\
LAB & $15.8^{2}$ & 57.7 & 0.274 & Pércz ct al. (1998) \\
SAB & $14.7^{2}$ & 60.9 & 0.242 & \\
Pure bacterial strains & 29.8 & 52.6 & 0.589 & Obispo and Dehority (1999) \\
Mixed rumen bacteria & 13.8 & 66.0 & 0.209 & \\
Mixed rumen bacteria & 14.4 & 75.2 & 0.193 & \\
LAB & $17.3^{2}$ & 68.2 & 0.253 & Martín-Orúc et al. (1998) \\
SAB & $11.5^{2}$ & 64.7 & 0.178 & \\
LAB & 10.0 & 58.1 & 0.172 & Volden et al. (1999) \\
SAB & 8.2 & 62.4 & 0.131 & \\
Protozoa & 10.2 & 66.8 & 0.153 & \\
\hline & & & & \\
\hline
\end{tabular}

' calculated assuming a mean molar adenine:guanine ratio of $1: 1.70$ for nixed rumen bacleria (Volden et al.. 1999)

' calculated assuming a molar adenine:guanine ratio of $1: 1.63$ and 1:1.76, for $L A B$ and $S A B$, respectively (Volden et al., 1999)

prediction of MP supply can be biased by the use of a purine:N ratio isolated from a single microbial fraction. In common with other microbial markers, obtaining representative samples of rumen microbes is fundamental to the accuracy of the PD technique. While it is important to understand and quantify the sources of variation affecting the purine: $\mathrm{N}$ ratio of rumen microbes, it is also important to 
recognise that obtaining such information requires the use of surgically modified animals and immediately negates the inherent non-invasive advantages of the PD technique.

\section{DIGESTION OF NUCLEIC ACIDS}

Microbial and dietary purines escaping ruminal degradation are generally absorbed in the form of nucleosides (Wilson and Wilson, 1962; McAllan, 1980). Duodenal NA bases, nucleosides and nucleotides in ruminants are degraded to varying degrees by pancreatic ribonuclease, pancreatic nucleases, phosphodiesterases, nucleotidase and nucleosidase secreted in the small intestine. Pancreatic ribonuclease activity is particularly high in the ruminant (Barnard, 1969) indicating their capacity to digest large quantities of NAs. Nucleosides, NAs and free bases are subsequently absorbed from the intestinal lumen (Fox, 1978). Free NAs entering the small intestine are almost entirely digested and absorbed in sheep (Ellis and Blechner, 1969b; Jackson et al., 1976) and in cattle (McAllan, 1980). Studies in ruminants have also indicated that the apparent digestibility coefficient between the proximal duodenum and distal ileum is higher for microbial RNA (0.87-0.97) than microbial DNA (0.75-0.85; Condon et al., 1970; Smith and McAllan, 1971; Storm and Ørskov, 1983; Storm et al., 1983). Disappearance of RNA due to digestion and absorption has been shown to be almost complete as digesta enters the jejunum (McAllan, 1980; Schönhusen et al., 1999). When corrected for endogenous losses, true digestibility coefficients of $0.859,0.780-0.871$ and 0.913 , have been reported for microbial NA-N (Storm and Ørskov, 1983), RNA-N (Storm and Ørskov, 1983; Schönhusen et al., 1999) and purines (Chen et al., 1990a), respcctivcly.

Digested nucleosides and free bases, with the exception of hypoxanthine are almost entirely absorbed before reaching the terminal ileum in ruminants (McAllan, 1980; 1982). In vitro studies of purine absorption in the hamster have shown that hypoxantine, xanthine and to a lesser extent uric acid are preferentially excreted rather than absorbed across the intestine (Berlin and Hawkins, 1968), while studies in sheep have indicated that the capacity of the small intestine to absorb allantoin is limited (Chen et al, 1990b). Nucleic acids, free bases (except xanthinc) and PDs entering the large intestine do not appear to be absorbed duc to extensive degradation by indigenous microbes (Sorensen, 1960; Ellis and Bleichner, 1969a; Chen et al., 1990a), and therefore purines excreted in faeces appear to be primarily derived from microbes residing in the caecum (Surra et al., 1997b). Furthermore, variations in the supply of NAs entering the caccum and the extent of hindgut fermentation do not appear to affect urinary PD excretion, but there is evidence to suggest that it is positively influenced by the flow of undigested fibre in the duodenum (Surra et al., 1997b). 


\section{FATE OF ABSORBED PURINES}

Exogenous absorbed purines undergo extensive degradation during their passage through intestinal mucosa (Wilson and Wilson, 1962), due to the presence of guanine deaminase (EC 3.5.4.3.; Henderson and Paterson, 1973), adenosine deaminase (EC. 3.5.4.4; Barman, 1969) and xanthine oxidase (EC 1.2.3.2.; Roussos, 1963; Al-Khalidi and Chaglassian, 1965; Chen et al., 1990c) in intestinal mucosa. The activity of xanthine oxidase that catalyses the irreversible oxidation of xanthine and hypoxanthine to uric acid is particularly important, since it determines the substrate pool available to salvage pathways that allow purine moities to be re-utilized for tissue NA synthesis. Studies in rats have shown that only adenine can cross the intestinal mucosal membrane (Savaiano et al., 1980), but an absence of nucleotides, nucleosides (except inosine), guanine and adenine in ovine and bovine portal blood (Balcells et al., 1992), suggests that this may not occur in ruminant specics.

Concentrations of non-oxidized PDs (hypoxanthine and xanthine) in portal blood have been shown to be much lower in bovine than ovine species (Balcells et al., 1992), and is consistent with observations that the activity of xanthine oxidase is higher in the intestinal mucosa of cattle than sheep (Al-Khalidi and Chaglassian, 1965). Based on these observations, it appears that purine compounds are catabolized immediately after absorption in the bovine and therefore intestinal is the only potential sitc for salvage of exogenous purines (Verbič et al., 1990; Balcells et al., 1992). In contrast, hypoxanthine and xanthine are present in both portal and peripheral blood in sheep (Chen ct al., 1990c; Balcells et al., 1992) as a consequence of only minor xanthine oxidase activity in intestinal mucosa and moderate activity in hepatic tissue (Al-Khalidi and Chaglassian, 1965). Consequently, it appears that in the ovine, absorption of exogenous purines leads to the formation of metabolites which can potentially be incorporated into tissue NAs.

\section{PURINE METABOLISM}

Purines are synthesized in mammalian tissues to replace obligatory losses incurred during cellular NA turnover and to satisfy purine accretion requirements during cellular growth. Synthesis of purine ribonucleosides occurs through two distincly different routes, commonly referred to as the de novo and salvage pathways.

De-novo synthesis

De novo purine synthesis has been extensively reviewed in the literature (refer to Hartman, 1970; Gots, 1971; Henderson and Patterson, 1973) and is only briefly 
documented. Tissue de novo purine synthesis proceeds using 5'-phosphoribosyl1 '-pyrophosphate (PRPP) as a building block onto which glycine, glutamine, aspartate, one carbon unit and carbon dioxide precursors are incorporated to yield a purine ring (Lchninger, 1982). On completion of the purine ring, inosine 5'-monophosphate (the nucleotide of hypoxanthine) is produced which can be converted to guanine or adenine nucleosides (Figure 2). However, de novo purine synthesis is absent in certain tissues such as bone marrow in the rabbit (Smellic et al., 1958; Thomson ct al.. 1960) and leukocytes in humans (Scott, 1962; Williams, 1962), and therefore purine requirements of these tissues are satisfied by other tissues, such as the liver which has been shown to be a major site of purine synthesis (Murray, 1971).

\section{Salvage pathways}

Purines liberated during tissue NA catabolism and exogenous purines derived from the gut, can be re-utilized via salvage pathways initiated by purine phosphoribosyltransferases (PRTases), cnzymes that are present in most mammalian tissues (Burridge et al., 1976). Studies in sheep using radio-labelled exogenous purines have confirmed that absorbed purine moities can be salvaged and re-utilized for the synthesis of nucleotides and NAs (Condon et al., 1970; Smith et al., 1974; Razzaque et al., 1981). Even in the absence of absorbed exogenous purines, salvage pathways still operate, avoiding the considerable energetic costs associated with de novo synthesis (Mura et al., 1987). In humans, it is estimated that up to $90 \%$ of the free purines produced during tissue NA turnover may be recycled via salvage pathways (Lehninger, 1982).

Purine salvage catalysed by PRTases results in the formation of nucleotide units from adenine, guanine and hypoxanthine precursors (Figure 2). Xanthine may be salvaged by hypoxanthine-guanine PRTase to form xanthine monophosphate (Gots, 1971 ), but this reaction is very slow due to a low affinity of xanthine for this enzyme (Hitchings, 1978). Purine bases can also be salvaged by combining with ribose 1'-phosphate to yield their respective nuclcosides. The reactions catalysed by nucleoside phosphorylases are quantitatively much less important than those proceeding via PRTases (Lehninger, 1982). Purine nucleotides derived from de novo synthesis or salvage pathways can be converted into nucleotides of other purine bases via a common intermediate inosine 5'-monophosphate. This mechanism enables cells to maintain the desired nucleotide pool composition.

The energetic cost of a mole of purine mononucleotides via salvage is 2 ATP, while de novo synthesis of adenosine 5'-monophosphate (AMP) and guanosine 5'-monophosphate (GMP) requires 8 and 7 ATP, respectively (Lehninger, 1982). In the presence of dietary (exogenous) purines it appears that enzyme activites involved in purine salvage are enhanced, while those integral to de novo synthe- 
sis are effectively switched off (Leleiko et al., 1979). Furthermore, administration of allopurinol (an allostearic inhibitor of xanthine oxidase), resulting in an accumulation of hypoxanthine, has also been shown to stimulate purine salvage enzymes (D'Mello, 1982). In the light of the considerable energetic advantage of salvaging purine bases compared to their de novo synthesis, salvage of ab-

\section{De novo synthesis}

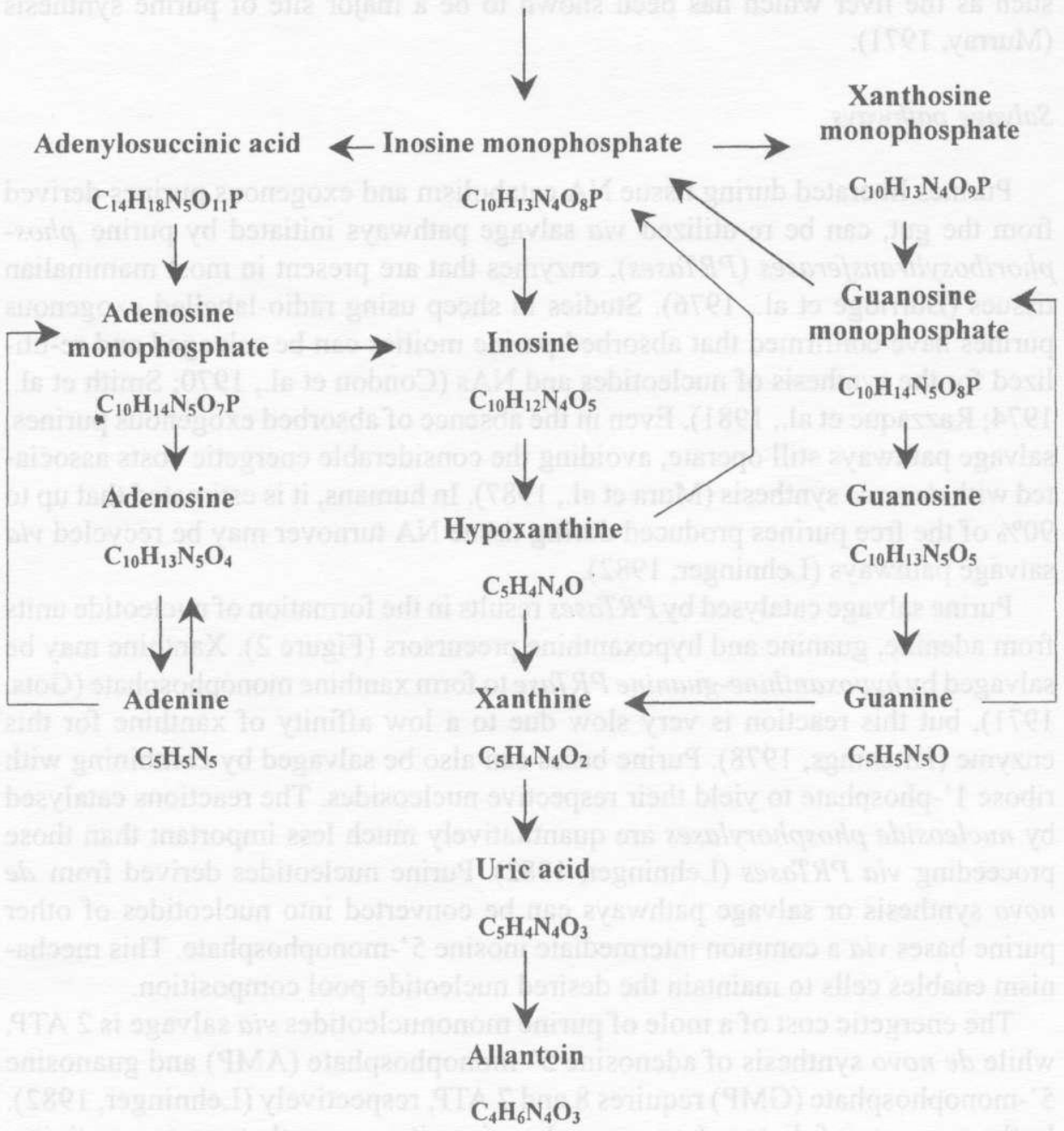

Figure 2. Purine metabolic pathways in ruminant tissues 
sorbed purines would be expected to be fully exploited in the ruminant (D'Mello, 1982; Kahn and Nolan, 1993).

Purine salvage is subject to feed-back control of purine nucleotides. Once cellular levels of purine nucleotides have been attained, further nucleotide loading will inhibit adenine-PRTase and hypoxanthine-guanine PRTase activities (Murray, 1971). Regulation of enzymatic activities also influences the cellular uptake of salvage substrates due to their uptake being proportional to PRTase activities (Gots, 1971). Once cellular purine nucleotide requirements are met, surplus nucleosides and free bases are diverted towards catabolic pathways leading to the formation of purine metabolites.

\section{Purine catabolism}

Turnover of cellular DNA tends to be relatively low, while turnover rates of certain RNA molecules such as mRNA are particularly rapid. During cellular NA turnover, DNA and RNA are hydrolysed by nucleases and diesterases to yield mono-nucleotides and nucleosides, of which the latter can be re-utilized and incorporated into NAs or further catabolized. Degradation of nucleoside molecules involves enzymatic cleavage of glycosidic bonds between purine bases and sugar moieties, yielding purine bases which can be either salvaged or further oxidized.

Catabolism of AMP and adenine leads to the formation of hypoxanthine, that is further oxidized to xanthine and uric acid in the presence of xanthine oxidase (Figure 2). Guanine nucleosides and bases enter the catabolic pathway as xanthine, which in the presence of xanthine oxidase is oxidized to uric acid. Finally, in the presence of uricase, uric acid is oxidized to liberate allantoin. the major purine catabolite in ruminant species. In most mammals, allantoin is the end product of purine catabolism, but purine catabolic pathways can be restricted to uric acid such as in primates, or can proceed beyond allantoin to glyoxylic acid and urea in evolutionary less developed animals such as fish.

\section{PURINE METABOLITE EXCRETION IN RUMINANT SPECIES}

\section{Renal clearance}

The appearance of hypoxanthine, xanthine and uric acid in ovine (Lindberg et al., 1989; Chen et al., 1990a,c; Lindberg and Jacobssen 1990; Balcells et al., 1991) and caprine (Lindberg, 1985, 1991) urine indicates a high renal clearance of these compounds. Further studies have established a PD clearance rate constant of approximately $33 \% / \mathrm{h}$ in sheep (Chen et al., 1991) and cattle (Giesecke 
et al., 1993). Short term infusions of exogenous purines in sheep have established that purine metabolites are excreted in urine within $2-3 \mathrm{~h}$ after their appearance in plasma (Chen et a1., 1997). Greger et al. (1976) reviewed the available literature and concluded that the renal clearance of allantoin occured within the glomerulus of the mammalian kidney without subsequent reabsorption or secretion along the nephron. However, more recent observations in shecp have indicated that the renal clearance of allantoin is marginally, but significantly less than $100 \%$, suggesting that tubular reabsorption of allantoin accounts for proportionately 0.05-0.09 of filtered load (Faichney and Welch, 1994).

The extent of urinary PD excretion is governed by the concentration of these compounds in plasma, the glomerular filtration rate (GFR) and the transport maximum from the renal tubule (Chen et al., 1997). Examination of the relationship between plasma purine metabolite concentrations and urinary PD excretion has indicated considerable between-animal variation in the GFR of PDs ranging between 137-145 (Chen et al., 1991) and 140-233 1/d (Chen et al., 1997) for sheep nourished by intra-gastric infusion, and between $65-158 \mathrm{l} / \mathrm{d}$ (Chen et al., 1991; Surra et al., 1997a) for conventionally fed animals. Studies in steers have also indicated large variations in the GFR of allantoin (range $847-1155 \mathrm{l} / \mathrm{d}$ ) that were independent of a functional rumen (Giesecke et al., 1993), tentatively suggesting that renal clearances are unaffected by the supply of PDs entering the bloodstream.

Renal clcarance of uric acid involves complicated post-filtration secretion and reabsorption processes occuring in the nephron and the Loop of Henle in the mammalian kidney (Greger et al., 1976). Despite these complications, measurements in steers have suggested that the GFR of uric acid (mean $965 \mathrm{l} / \mathrm{d}$ ) approaches that of allantoin (mean $984 \mathrm{l} / \mathrm{d}$; Gicsecke et al., 1993). In contrast, studies in sheep have demonstrated that the renal clcarance of uric acid $(671 \mathrm{l} / \mathrm{d})$, hypoxanthine $(289 \mathrm{l} / \mathrm{d})$ and xanthine $(11.2 \mathrm{l} / \mathrm{d})$ is different to that of allantoin $(113 \mathrm{l} / \mathrm{d})$, a finding explained by variations in net tubular secretion or reabsorption of individual PDs (Surra et al., 1997a).

Abomasal infusions of exogenous purines in sheep (Chen et al., 1990a; Balcells et al., 1991; Chen et al., 1997) and cattle (Verbič et al., 1990; Vagnoni et al., 1997) have indicated that renal clearance is quantitatively the most important excretory route, accounting for proportionately between 0.83 and 0.88 of absorbed exogenous purines. In cattle, the proportion of PDs excreted as allantoin is relatively constant ranging between 0.82 and 0.93 (Chen et al., 1990c, 1992c; Verbič et al., 1990; Giesecke et al., 1994; Vagnoni and Broderick, 1997; Vagnoni et al., 1997; Shingfield and Offer 1998a,b; Valadares et al., 1999), while the remainder is excreted as uric acid, since bovine urine contains only trace amounts of xanthine and hypoxanthine (Susmel et al., 1994; Shingfield and Offer, 1999a). Pooling data from several dairy cow experiments $(n=7)$ has also demonstrated 
that urinary $\mathrm{PD}$ excretion $(\mathrm{Y}, \mathrm{mmol} / \mathrm{d})$ is closely correlated with urinary allantoin excretion $(\mathrm{x}, \mathrm{mmol} / \mathrm{d})$, where:

$$
\begin{aligned}
& Y=11.190 \text { (s.c. } 3.588)+1.105 \text { (s.e. } 0.014) x \\
& (n=180, r=0.986, P<0.001 ; \text { Shingfield et al., unpublished data). }
\end{aligned}
$$

This relationship indicates that for cattle, urinary PD excretion can be accurately predicted from measurements of allantoin alone, confirming the suggestions of Dewhurst et al. (1996).

In contrast, the composition of PDs excreted in the urine of shcep and goats appears to be more variable. Chen et al. (1990a) reported that in shecp the proportion of PDs excreted as allantoin increased with exogenous purine supply, while catabolism of endogenous and exogenous purines have resulted in different PD profiles in caprine urine (Lindberg, 1991). These findings tend to suggest that the PD composition of caprine and ovine urine reflects differences in the site of metabolite formation due to changes in the relative proportions of endogenous and exogenous purines entering catabolic pathways. However, experimental observations are conflicting. Condon and Hatficld (1970) reported increases in non-allantoin metabolites in ovine urine at high duodenal RNA infusions, while Giesecke et al. (1984) detected significant increases in hypoxanthinc excretion of sheep in response to duodenal RNA infusions. However, Balcells et al. (1991) reported that only allantoin excretion increased with incremental increases of duodenal purines in sheep, a finding inconsistent with that of Lindberg (1991) and Kahn and Nolan (1993) indicating that the proportions of PDs were constant over a range of exogenous purine supplies in goats and shecp, respectively. Some studies have provided evidence to suggest that measurements of allantoin alone could be used to predict the excretion of all PDs in ovine urine (Balcells et al., 1991; Puchala and Kulasek, 1992). However, the extent of variation in the PD composition of ovine and caprine urine has lead to the general conclusion that all catabolites need to measured to accurately assess urinary PD excretion in these species (Giesecke et al., 1984; Fujihara ct al., 1987; Lindberg et al., 1989). Typical urinary PD excretion in ruminant species is presented in Table 2.

\section{Mammary secretion}

The presence of purine and pyrimidine metabolites in bovine milk has long been recognized (Deutsch and Mattsson, 1959). Purine moieties are primarily excreted as allantoin and uric acid, since ruminant milk contains only trace amounts of xanthine and hypoxanthine (Tiermeyer et al., 1984; Martín-Orúc et al., 1996). Mammary secretion of allantoin is thought to be due to diffusion from plasma into the mammary alveolar lumen (Tiermeyer et al., 1984; Gicsecke et al., 1994). Uric 
TABLE 2

Typical urinary purine metabolite excretion of conventionally fed ruminant species reported in the literature

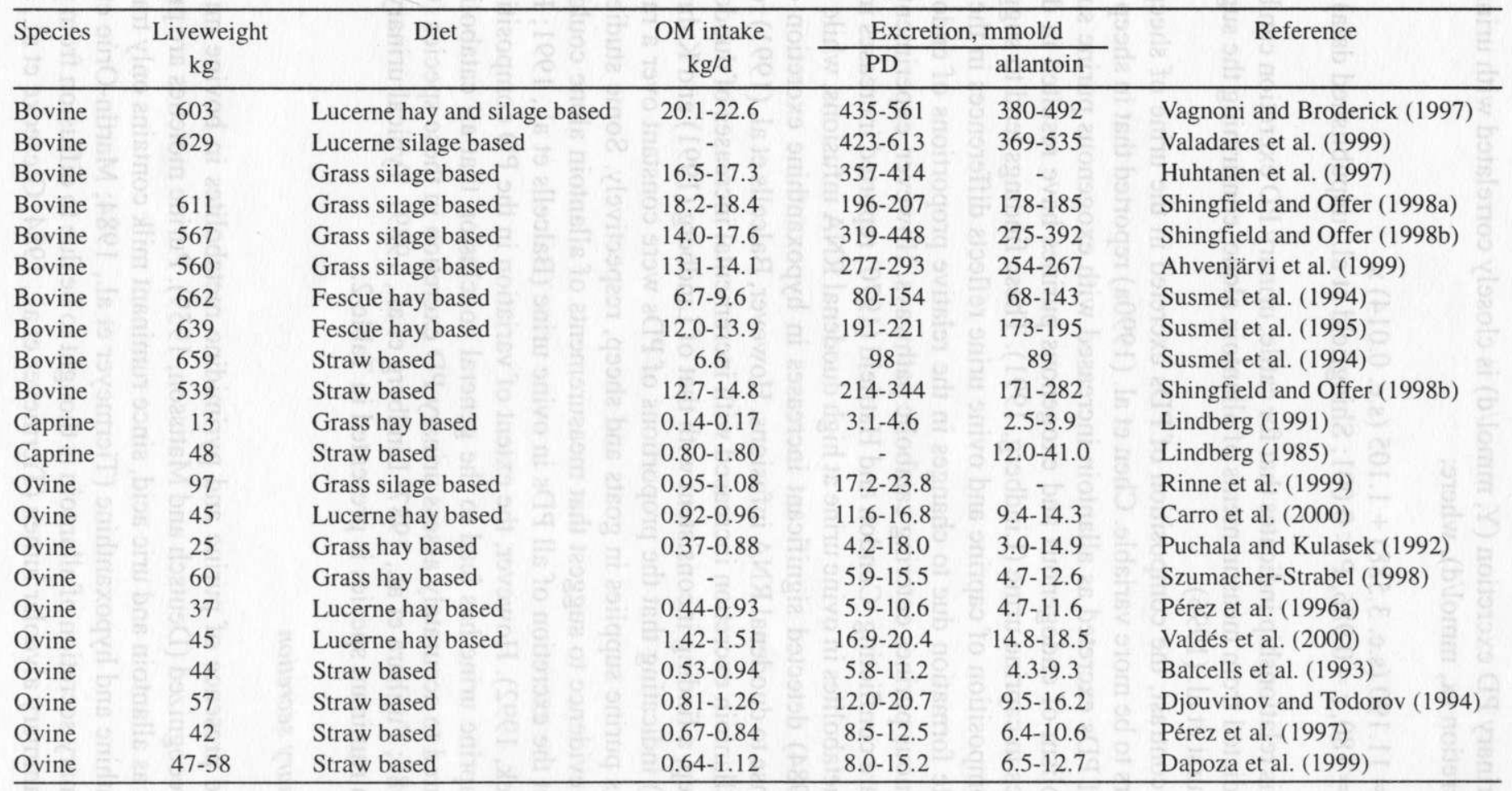


acid secreted in milk appears to be derived from plasma and as a consequence of endogenous mammary purine metabolism (Rosskopf et al., 1991; Giesecke et al., 1994). Early studies in dairy cows estimated that allantoin secretion in milk accounted for proportionately 0.06-0.07 of that excreted in urine (Kirchgessner and Kreuzer, 1985; Kirchgessner and Windisch, 1989). Subsequent studies in dairy cows have reported values of between 0.04 and 0.12 (Susmel et al., 1995; Vagnoni and Broderick, 1997; Valadares et al., 1999). However, these estimates are subject to criticism due to a lack of specificity of colorimetric based methods used for the quantification of allantoin in milk and urine. Use of more specific and sensitive analytical methods based on high performance liquid chromatography have indicated that mammary secretion accounts for proportionately between $0.006-0.03$ of urinary allantoin excretion in ruminant species (Giesecke et al., 1994; MartínOrúe et al., 1996; Gonda and Lindberg, 1997; Shingfield and Offer, 1998b). Secretion of uric acid in milk has been reported to account for proportionately 0.03 and 0.17 of urinary excretion in cows (Giesecke et al., 1994; Valadares et al., 1999) and sheep (Martín-Orúe et al., 1996), respectively.

\section{Salivary secretion}

Based on an assumed salivary flow of $10 \mathrm{l} / \mathrm{d}$, Chen et al. (1990b) estimated that secretion of PDs into the gastro-intestinal tract accounted for proportionatcly 0.10 of urinary excretion in sheep. Using the same estimate of salivary flow and intravenous infusions of ${ }^{14} \mathrm{C}$-adenine to assess purine metabolism, Kahn (cited by Kahn and Nolan, 1993) reported that salivary PD losses accounted for 0.27 of that excreted in urine. In contrast, Surra et al. (1997a) using Co-EDTA as a marker of salivary flow, reported that losses in saliva accounted for only 0.001 of urinary PD excretion. Large discrepancies between estimates of purine losses via saliva are difficult to reconcile, since these large differences cannot be satisfactorily explained by dietary induced variations (Kay, 1966) or incorrect assumptions of salivary flow.

\section{Enteric secretion}

In humans uric acid is removed from blood into the gut by direct passage or via gastro-intestinal secretions (Sorensen, 1978). Faecal recovery of radioactivity $(0.13)$ following intra-venous infusions of ${ }^{13} \mathrm{C}$ guanine indicate PDs are also secreted into the gut of pigs (Simmonds et al., 1973). Kahn and Nolan (1993) reported that in sheep, urinary recovery $(0.19)$ of intravenously administered ${ }^{14} \mathrm{C}$ adenine was much lower than the amount of tracer (0.48) entering blood bicarbonate. Discepancics between ${ }^{14} \mathrm{CO}_{2}$ entering the blood bicarbonate pool and that which could be accounted for hepatic catabolism of uric acid to allantoin, 
were attributed to microbial degradation of purines secreted in bile and other gastro-intestinal secretions. These findings tentatively suggest that enteric losses of PDs in ruminants may be quantitatively more important than secretion in milk or saliva.

\section{IMPLICATIONS}

Recovery of exogenous purines

Use of PD excretion as an index of MP supply is dependent on establishing the relationship between exogenous purine supply and excretion of purine metabolites, such that any variability in this relationship is known or at least predictable. Numerous studies have been conducted in order to assess the relationship between duodenal exogenous purine flow and urinary PD excretion. Since exogenous purines can enter salvage pathways and used as substrates for tissue NA synthesis in ovine species (Ellis and Bleichner, 1969b; Condon et al., 1970; Smith et al., 1974; Razzaque et al., 1981; Kahn, 1991, cited by Kahn and Nolan, 1993), urinary recoverics of infused purines reported in sheep have been subject to considerable variation (Table 3). Data from early experiments (Antoniewicz et al., 1980; Gicsecke et al., 1984; Fujihara et al., 1987) was interpreted assuming a linear relationship between exogenous purine supply and urinary PD excretion, with the implication that $\mathrm{PD}$ excretion derived from endogenous sources remains constant across a range of exogenous purine loads. More recent observations have lead to the suggestion that this relationship is curvi-linear (Chen et al., 1990a, 1997; Balcells et al., 1991; Puchala and Kulasek, 1992;), due to the contribution of de novo purine synthesis at low exogenous purine loads necessary to compensate for limited amounts of absorbed exogenous purines entering salvage pathways, constituting a net endogenous purine loss. Use of quadratic models to fit experimental data describing the relationship between absorption of exogenous purines and urinary PD excretion indicate that once salvage of exogenous purines operates at a maximal rate, proportionately between 0.81 and 0.87 of absorbed purines are excreted as PDs in urine (Chen et al., 1990a,1997; Balcells et al., 1991). If the models proposed are correct, then the corollary is that the complications of determining endogenous PD excretion in sheep are removed when fed diets supplying in excess of maintenance energy requirements (Figure 3 ).

In contrast to the observations in sheep, urinary recoveries of infused purines in cattle tend to be much more consistent (Table 3). Less variation in urinary PD responses to exogenous purine inputs has been attributed to the confinement of exogenous purine salvage to the intestinal mucosa, due to high xanthine oxidase 
TABLE 3

Urinary recovery of exogenous purines

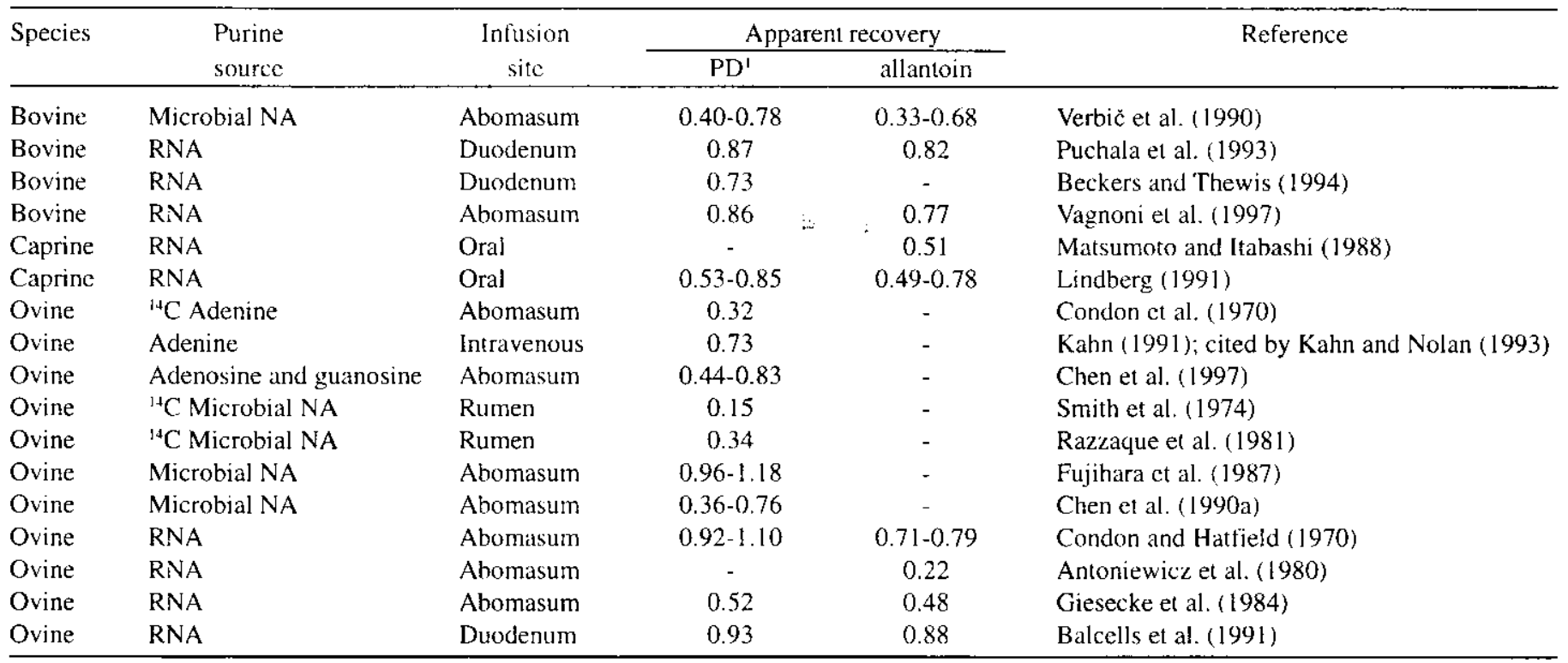

'refers to purine derivatives calculated as the sum of allantoin, hypoxanthine, uric acid and xanthine 


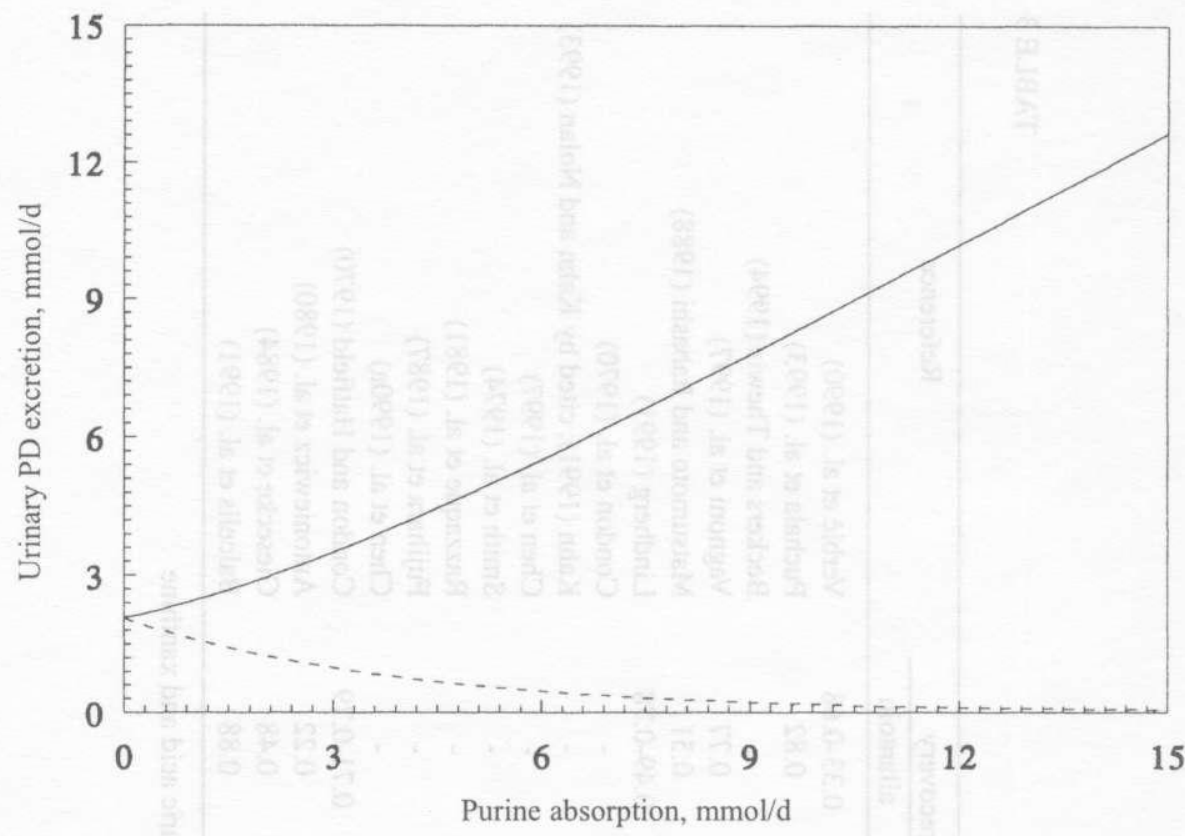

Figure 3. Relationship between purine absorption and urinary purine derivative (PD) excretion in sheep based on the data of Chen et al. (1990a).

Solid line indicates urinary PD excretion derived from exogenous and endogenous purines, dotted line indicates urinary PD excretion derived from endogenous purines

activities in other bovine tissues (Verbič et al., 1990). Use of a quadratic model to fit experimental data, indicated that proportionately 0.85 of absorbed purines are excreted as PDs in urine, and that once salvage pathways accounting for 0.22 of endogenous purine losses are saturated, urinary PD excretion derived from endogenous purine metabolism is independent of exogenous purine supply (Verbič et al., 1990; Figure 4). Assuming that this model is correct, the implication is that endogenous purine losses have to be taken into account in cattle.

Despite recent observations in cattle that proportionately 0.86 of exogenous purines were recovered as PDs excreted in the urine (Vagnoni et al., 1997), the validity of recently proposed models remains largely uncertain. Mean urinary recoveries of intravenous allantoin infusions of proportionately between $0.72-0.78$ in sheep (Chen et al., 1991; Surra et al., 1997a) and 0.70 in cattle (Giesecke et al., 1993), tends to raise concerns over the accuracy of the coefficients used to describe the relationship between purine absorption and urinary PD excretion. Furthermore, Kahn and Nolan (1993) noted that the feedback control of de novo purine synthesis has not been experimentally verified, and questioned why mammals 


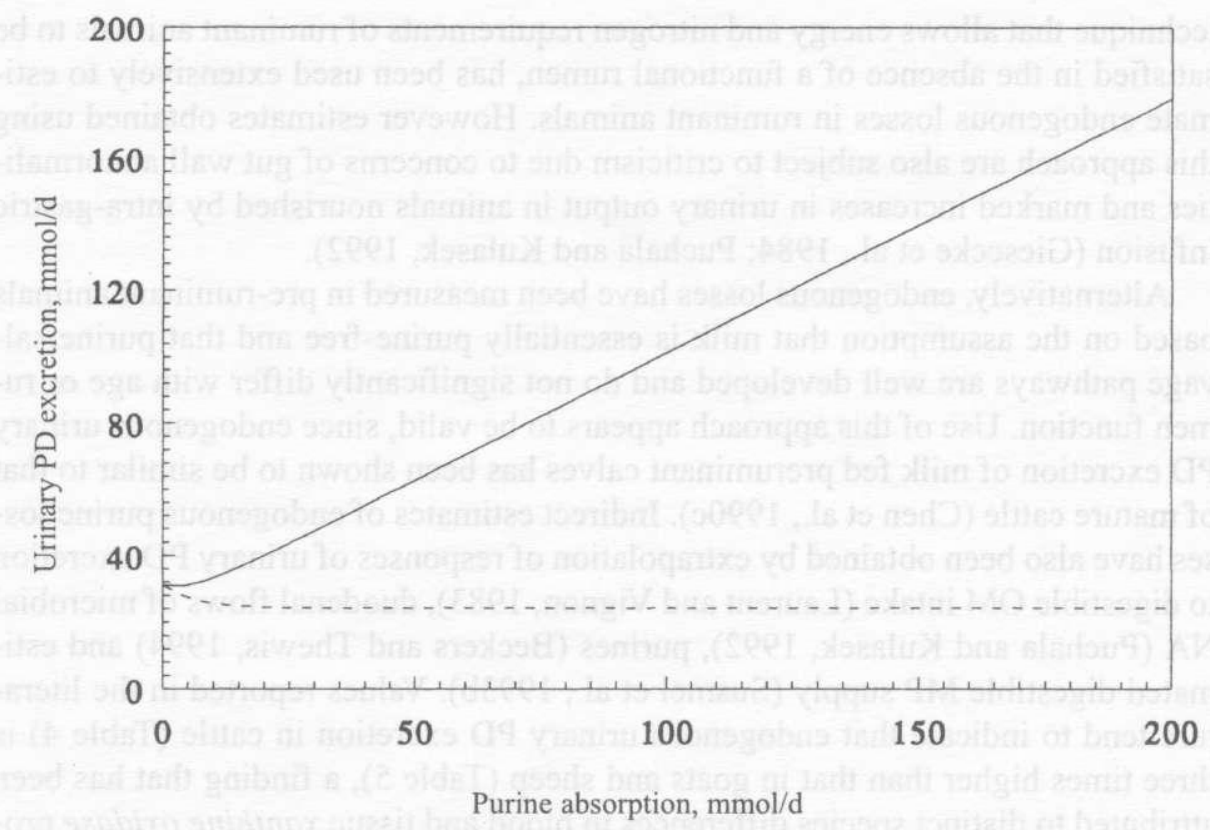

Figure 4. Relationship between purine absorption and urinary purine derivative (PD) excretion in cattle based on the data of Verbič et al. (1990).

Solid line indicates urinary PD excretion derived from exogenous and endogenous purines, dotted line indicates urinary PD excretion derived from endogenous purines

in general, and ruminants in particular, need to synthesise any purines de novo, in light of the abundant supplies of exogenous purines and high energetic costs of purine biosynthesis.

\section{Endogenous purine losses}

Purine metabolites excreted in ruminant urine are primarily derived from absorbed exogenous purines, but as a consequence of tissue adenosine triphosphate and NA turnover, a proportion of purine bases are not salvaged and re-utilized, but enter catabolic pathways, constituting an endogenous loss. Several approaches have been used to assess urinary purine losses in ruminant animals. Early studies attempted to measure endogenous losses in sheep during periods of fasting (Morris and Ray, 1939; Walker, 1967; Ryś et al., 1973, 1975), but negligible urinary excretion of PDs after several days of fasting, suggests that these estimates are erroneous due to extensive purine salvage and a potential reduction in NA turnover associated with reduced nutrient availablity. More recently, the intra-gastric infusion 
technique that allows energy and nitrogen requirements of ruminant animals to be satisfied in the absence of a functional rumen, has been used extensively to estimate endogenous losses in ruminant animals. However estimates obtained using this approach are also subject to criticism due to concerns of gut wall abnormalities and marked increases in urinary output in animals nourished by intra-gastric infusion (Giesecke et al., 1984: Puchala and Kulasek, 1992).

Alternatively, endogenous losses have been measured in pre-ruminant animals based on the assumption that milk is essentially purine-free and that purine salvage pathways are well developed and do not significantly differ with age or rumen function. Use of this approach appears to be valid, since endogenous urinary PD excretion of milk fed preruminant calves has been shown to be similar to that of mature cattle (Chen et al., 1990c). Indirect estimates of endogenous purine losses have also been obtained by extrapolation of responses of urinary PD excretion to digestible OM intake (Laurent and Vignon, 1983), duodenal flows of microbial NA (Puchala and Kulasek, 1992), purines (Beckers and Thewis, 1994) and estimated digestible MP supply (Susmel et al., 1993b). Values reported in the literature tend to indicate that endogenous urinary PD excretion in cattle (Table 4) is three times higher than that in goats and sheep (Table 5), a finding that has been attributed to distinct species differences in blood and tissue xanthine oxidase profiles (Chen et al., 1990c).

Use of measurements reported in the literature to account for endogenous purine losses in conventionally fed ruminants have to be applied with caution, since the influence of nutrient availability on the extent of endogenous losses remains unclear. Endogenous urinary allantoin excretion of ruminant animals maintained by intra-gastric infusion have in several cases been shown to be independent of $\mathrm{N}$

TABLE 4

Endogenous urinary purine derivative (PD) excretion in cattle

\begin{tabular}{|c|c|c|c|c|}
\hline \multirow[t]{2}{*}{ Animal } & \multicolumn{2}{|c|}{ Excrction, $\mu \mathrm{mol} / \mathrm{W}^{0.75} / \mathrm{d}$} & \multirow[t]{2}{*}{ Nutrient supply } & \multirow[t]{2}{*}{ Reference } \\
\hline & $\mathrm{PD}^{\prime}$ & allantoin & & \\
\hline Calves & $443-613$ & $329-494$ & Milk fed calves & Chen et al. (1990c) \\
\hline Cows & 429 & - & Conventionally fed & Susmel et al. (1993b) \\
\hline Cows & 513 & 424 & Intra-gastric infusion & Chen et al. (1990c) \\
\hline Steers & 560 & 488 & Conventionally fed & Giesecke et al. (1993) \\
\hline Steers & 531 & - & Conventionally fed & Beckers and Thewis (1994) \\
\hline Steers & - & $375-447$ & Intra-gastric infusion & Sibanda et al. (1982) \\
\hline Steers & $443-468$ & - & Intra-gastric infusion & Fujihara et al. (1987) \\
\hline Steers & 428 & 365 & Intra-gastric infusion & Verbič et al. (1990) \\
\hline Steers & $401-571$ & $373-500$ & Intra-gastric infusion & Chen et al. $(1990 \mathrm{c})$ \\
\hline
\end{tabular}

1 refers to purine derivalives calculated as the sum of allantoin, hypoxanthine, uric acid and xanthine 
TABLE 5

Endogenous urinary purine derivative (PD) excretion in goats and sheep

\begin{tabular}{lccll}
\hline Species & \multicolumn{2}{c}{ Excretion, $\mu \mathrm{mol} / \mathrm{W}^{075} / \mathrm{d}$} & & Nutrient supply \\
\cline { 2 - 3 } & $\mathrm{PD}^{1}$ & allantoin & & Reference \\
\hline Caprine & - & $46-152$ & Conventionally fed & Laurent and Vignon (1983) \\
Caprine & 217 & 150 & Milk fed pre-ruminants & Lindberg (1989) \\
Caprine & 253 & 161 & Milk fed pre-ruminants & Lindberg (1991) \\
Ovine & - & 46 & Conventionally fed & Laurent and Vignon (1983) \\
Ovine & - & 140 & Conventionally fed & Puchala and Kulasek (1992) \\
Ovine & - & 156 & Mitk fed pre-ruminants & Antonicwic7. (1983) \\
Ovine & - & $22-44$ & Intra-gastric infusion & Antoniewicz and Pisulewski (1982) \\
Ovine & - & 161 & Intra-gastric infusion & Sibanda et al. (1982) \\
Ovine & 176 & Intra-gastric infusion & Giesecke et al. (1984) \\
Ovine & 165 & - & Intra-gastric infusion & Fujihara et al. (1987) \\
Ovine & $136-217$ & $68-109$ & Intra-gastric infusion & Lindberg and Jacobssen (1990) \\
Ovine & 168 & 93 & Intra-gastric infusion & Chen et al. (1990c) \\
Ovine & 176 & Intra-gastric infusion & Chen et al. (1997) \\
Ovine & 191 & 73 & Purine-free nutrient supply & Balcclls et al. (1991) \\
\hline
\end{tabular}

' refers to purine derivatives calculated as the sum of allantoin, hypoxanthine, uric acid and xanthine 
(Fujihara et al., 1987; Chen et al., 1990c; Lindberg and Jacobsson, 1990) and energy supply (Lindberg and Jacobsson, 1990). In contrast, Sibanda et al. (1982) reported that endogenous allantoin excretion in cattle was affected by energy and $\mathrm{N}$ supply, the extent of which was greatest when no nutrients were infused. Giesecke et al. (1984) also noted that endogenous allantoin excretion was higher in sheep receiving volatile fatty acid infusions that supplied 0.25 of maintenance energy requirements, findings that are consistent with increases in endogenous allantoin excretion of milk-fed goats during periods of restricted energy and $\mathrm{N}$ intake (Lindberg, 1989). Such apparent discrepancies concerning the influcnce of nutrient supply may potentially be reconciled as a result of differences in metabolic state, since changes in endogenous allantoin excretion appear to be positively and more closely related with changes in cumulative $\mathrm{N}$ balance than daily $\mathrm{N}$ intake or retention (Chen et al., 1992b). More recently, Shingfield and Offer (1999b) reported that urinary losses of pseudouridine, a modified pyrimidine metabolite that is liberated during tissue RNA turnover and obligately excreted in the urine, are positively related to energy intake in dairy cows. These findings suggest that tissue NA turnover is associated with the metabolic activity of an animal, and therefore variations in endogenous purine losses need to be taken into account if accurate predictions of MP supply are to be made from measurements of urinary PD excretion in cattle and in sheep fed at sub-maintenance.

\section{PREDICTION OF MICROBIAL PROTEIN BASED ON PURINE METABOLITES}

\section{Renal excretion}

Following the observations that purines entering the small intestine of ruminants are essentially microbial in origin, and that once purine salvage pathways are saturated, absorbed exogenous purines are quantitatively recovered in urine, a number of mathematical models have been proposed for the prediction of MP supply based on urinary PD excretion (Ryś et al., 1975; Chen et al., 1990a; Verbič et al., 1990; Balcells et al., 1991; Puchala and Kulasek, 1992). Despite considerable indirect evidence to support this approach, few studies have been conducted to validate the PD technique. Djouvinov and Todorov (1994) demonstrated on the basis of two experiments that mean treatment $(n=6)$ estimates of microbial $N$ supply predicted from urinary PD excretion according to Chen et al. (1990a) were closely correlated with values based on DAPA and purines ( $r$ values 0.982 and 0.995 , respectively). Further studies in sheep have also demonstrated close relationships between urinary PD and allantoin excretion with estimates of rumen microbial synthesis based on ${ }^{15} \mathrm{~N}$ and purines (Pérez et al., 1996a, 1997). However, predictions of MP supply based on urinary PD (Chen et al., 1990a) or allantoin 
(Balcells et al., 1991) excretion were consistently lower than direct measurements based on ${ }^{15} \mathrm{~N}$ or purines (Figure 5). Use of mean treatment values from both studies $(\mathrm{n}=16)$ indicates that relative to ${ }^{15} \mathrm{~N}$ based measurements, predictions based on urinary $\mathrm{PD}$ or allantoin excretion and measured purine: $\mathrm{N}$ ratios in rumen bacteria lead to a mean underestimation of MP supply of proportionately 0.16 and 0.25 , respectively. These findings tentatively suggest that response models used to predict MP supply in sheep underestimate the extent of non-renal PD excretion.

Data supporting the use of urinary PD cxcretion to estimate MP supply in dairy cows is less convincing than that reported in sheep. Johnson et al. (1998) on the basis of six studies reported weak and highly variable relationships between urinary PD excretion and estimates of microbial protein supply using purines as a microbial marker. Furthermore, excretion of uric acid was found to be morc closely correlated with MP supply than that of allantoin, which is surprising because allantoin is quantitatively the most important PD excreted in urinc. However, lack of relationships reported in these studies could potentially be cxplained by the exclusive use of LAB isolates, unreliable estimates of digesta flow due to the use of a single marker system and random experimental errors associated with the determination of purines and PDs using aspecific colorimetric based methods. In contrast, more recent data (Ahvenjärvi et al., unpublished) has shown that MP supply predicted from urinary PD excretion according to Verbič et al. (1990) to be moderately correlated with values based on purines (Figure 6) and indicated a positive bias in this relationship that tentatively suggests that endogenous purine losses $\left(385 \mu \mathrm{mol} / \mathrm{W}^{0.75} / \mathrm{d}\right)$ are underestimated in the response model proposed by Verbič et al. (1990).

\section{Mammary allantoin secretion}

Milk is easily sampled and routinely collected as part of national recording schemes, and therefore the secretion of PDs in milk could potentially be used as the basis for an on-farm diagnostic of MP supply. For this purpose it appears that only measurements of allantoin secretion would be of value, since uric acid is also derived from endogenous purine metabolism in the mammary gland (Rosskopf et al., 1991; Giesecke et al., 1994). Furthermore, a lack of uricase or uricase mRNA activity in mammary tissue (Motojima and Goto, 1990) tends to suggest that uric acid derived from endogenous sources is not subsequently oxidized to allantoin.

Several studies have shown that milk allantoin secretion is related to the intake of dietary crude protein (Kirchgessner and Kreuzer, 1985), OM (Gonda and Lindberg, 1997) and energy (Rosskopf et al., 1991; Lebzien et al., 1993; Giesecke et al., 1994). Furthermore, concentrations of allantoin in milk and plasma have been shown to be closely correlated (Rosskopf et al., 1991; Giesecke et al., 1994). Despite such promising indirect evidence, critical evaluation of milk allantoin secre- 

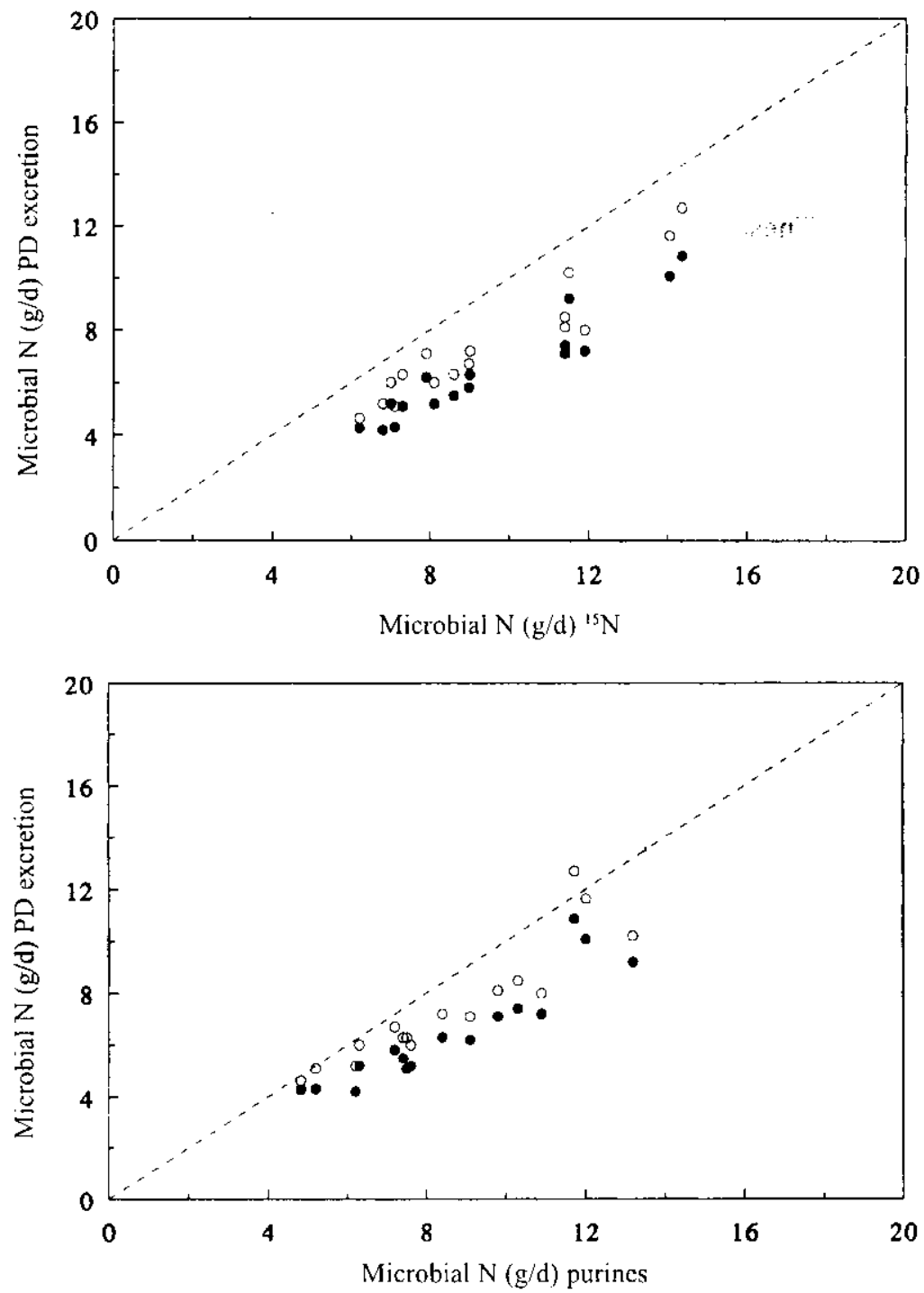

Figure 5. Comparison of microbial nitrogen flows $(\mathrm{g} / \mathrm{d})$ in sheep based on ${ }^{15} \mathrm{~N}$ purines and with estimates predicted from urinary purine derivative and allantoin excretion according to the response models of Chen et al. (1990a) and Balcelis et al. (1991), respectively

a) Comparison of microbial nitrogen flows ( $\mathrm{g} / \mathrm{d}$ ) based on ${ }^{15} \mathrm{~N}$ and urinary purine derivative $(\mathrm{O})$ and allantoin excretion $(\bullet)$

Data derived from Pérez ct al. (1996a, 1997). Dotted line indicates $y=x$

b) Comparison of microbial nitrogen flows $(\mathrm{g} / \mathrm{d})$ based on purines and urinary purine derivative $(\mathrm{O})$ and allantoin excretion $(\bullet)$

Data derived from Pérez ct al. (1996a, 1997). Dotted line indicates $y=x$ 


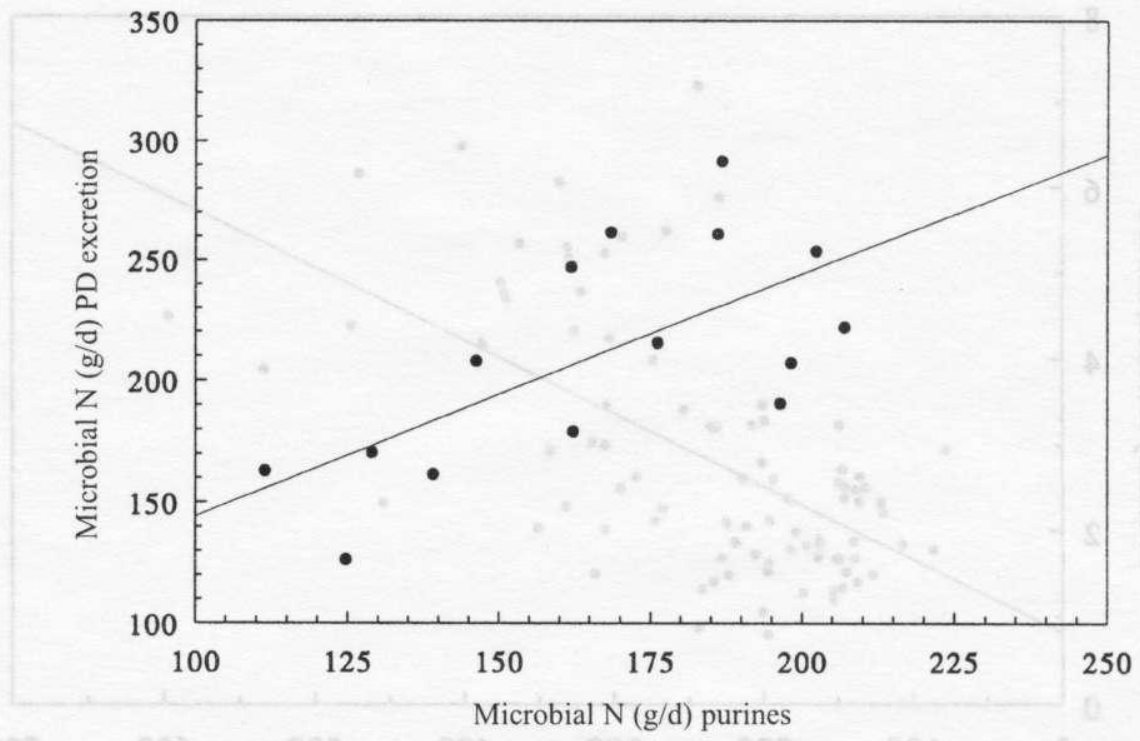

Figure 6. Comparison of microbial nitrogen flows $(\mathrm{g} / \mathrm{d})$ in dairy cows based on purines and estimates predicted from urinary purine derivative excretion according to the response model of Verbič et al. (1990)

Data derived from Ahvenjärvi et al. (unpublished).

Fitted line indicates correlation between microbial nitrogen flow predicted based on urinary PD excretion $(\mathrm{Y})$ and purines $(\mathrm{x})$ where:

$\mathrm{Y}=44.3$ (s.e. 53.0$)+1.00($ s.e. 0.31$) \times(n=15, r=0.663, P<0.01)$

tion as an indicator of MP supply is limited. Several studies have attempted to assess the value of milk allantoin measurements based on examination of the relationship between mammary and renal allantoin excretion. Martín-Orúe et al. (1996) reported that milk allantoin secretion in sheep was not significantly correlated with urinary allantoin or PD excretion. Gonda and Lindberg (1997) working with dairy cows, were also unable to identify a consistent relationship between urinary and milk allantoin excretion. Shingfield and Offer (1998b) attempted to evaluate the potential of milk allantoin in two experiments using diets formulated to supply different amounts of metabolisable and fermentable energy, that were assumed to cause differences in MP supply. Excretion and concentration of allantoin in milk was found to be closely correlated with urinary PD excretion, based on mean treatment values, but not when based on individual cow measurements (Figure 7), a finding attributed to mutual correlation of these parameters with milk yield. Since the prediction of urinary PD excretion was not improved by milk allantoin measurements, compared to that of milk yield alone, Shingfield and Offer (1998b) concluded that the secretion of allantoin appears to be of little value for the 


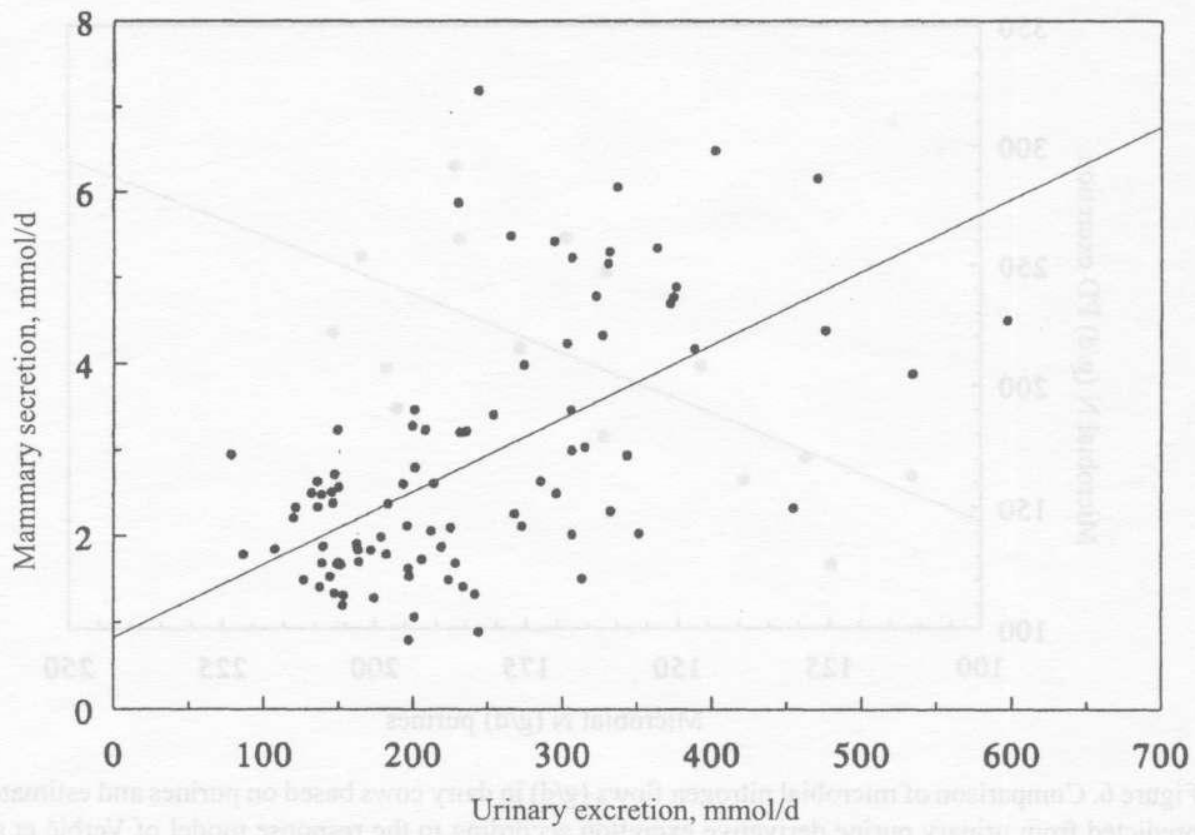

Figure 7. Relationship between mammary and urinary allantoin excretion in dairy cows.

Data derived from Shingfield and Offer (1998b).

Fitted line indicates correlation between mammary $(\mathrm{Y}, \mathrm{mmol} / \mathrm{d})$ and urinary allantoin $(\mathrm{x}, \mathrm{mmol} / \mathrm{d})$ excretion where:

$\mathrm{Y}=0.83$ (s.e. 0.31$)+0.0085$ (s.e. 0.0012$) \times(n=94 ; \mathrm{r}=0.594, \mathrm{P}<0.001)$

assessment of MP supply. These findings are consistent with those of Lebzien et al. (1993) indicating that estimates of MP supply based on ${ }^{15} \mathrm{~N}$ were less well correlated with milk allantoin excretion (r value 0.711 ; Figure 8 ) than dietary energy intake (r value 0.916).

\section{APPLICATION}

Despite being non-invasive, the widescale use of urinary PD excretion to predict MP supply in ruminant animals is constrained by the requirement for a total urine collection. Since urinary creatinine excretion has been considered as an internal marker of urinary output (De Groot and Aafjes, 1960; Erb et al., 1977), Antoniewicz et al. (1981) suggested that the molar ratio of PDs to creatinine $(\mathrm{PD} / \mathrm{c})$ in spot urine samples could be used to overcome these restrictions. Use of this approach is valid provided that renal clearances of PDs approach that of creati- 


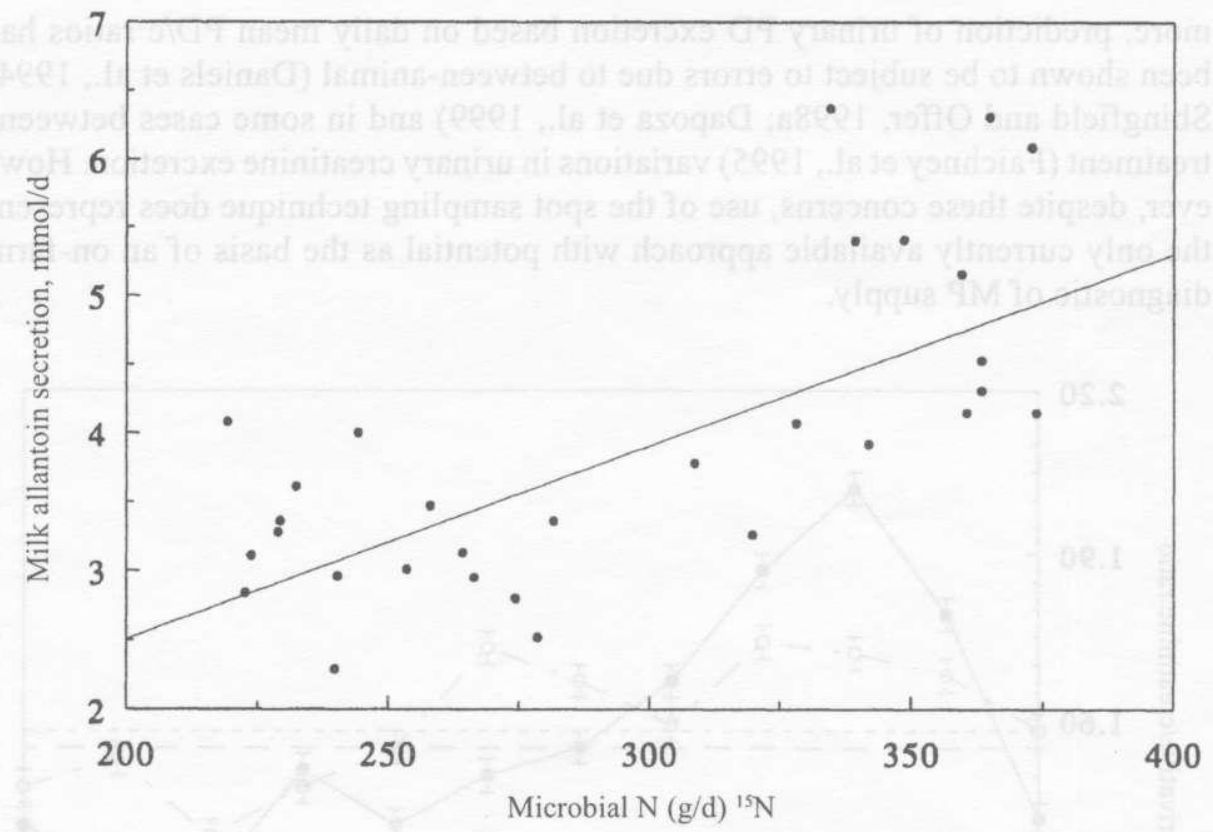

Figure 8. Relationship between mammary allantoin secretion and ${ }^{15} \mathrm{~N}$ based estimates of microbial nitrogen supply.

Data derived from Lebzien et al. (1993).

Fitted line indicates correlation between mammary allantoin secretion $(\mathrm{Y}, \mathrm{mmol} / \mathrm{d})$ and duodenal microbial nitrogen supply $(\mathrm{x}, \mathrm{g} / \mathrm{d})$ where:

$\mathrm{Y}=-0.294($ s.e. 0.800$)+0.014(0.003) \times(\mathrm{n}=30, \mathrm{r}=0.711, \mathrm{P}<0.001)$

nine, diurnal variations in spot sample $\mathrm{PD} / \mathrm{c}$ ratios are small or at least consistent and $\mathrm{PD} / \mathrm{c}$ ratios are closely correlated with daily PD excretion (Chen et al., 1995).

A number of studies in ruminant species (Antoniewicz et al., 1981; Chen et al., 1992c; Gonda and Lindberg, 1994; Dewhurst et al., 1996; Vagnoni and Broderick, 1997; Valadares et al., 1999) have reported that spot sample PD/c ratios are little affected by diurnal variation and closely correlated with urinary PD excretion (Chen et al., 1995; Dapoza et al., 1999). In contrast, Puchala and Kulasek (1992) demonstrated the dependence of spot sample $\mathrm{PD} / \mathrm{c}$ ratios on sampling time. A recent critical evaluation of the spot sampling technique indicated that within-day variations in urinary $\mathrm{PD} / \mathrm{c}$ ratios of two-hourly spot samples followed diurnal patterns, the extent of which was dependent on feeding grass silage and concentrate either separately or as a complete diet (Shingfield and Offer, 1998a; Figure 9). Since variations in $\mathrm{PD} / \mathrm{c}$ ratios were influenced by feeding system, it appears that establishing a valid sampling protocol which would be accurate for a range of diets and feeding systems, represents the largest constraint on the use of technique. Further- 
more, prediction of urinary $\mathrm{PD}$ excretion based on daily mean $\mathrm{PD} / \mathrm{c}$ ratios has been shown to be subject to errors due to between-animal (Daniels et al., 1994; Shingfield and Offer, 1998a; Dapoza et al., 1999) and in some cases betweentreatment (Faichney et al., 1995) variations in urinary creatinine excretion. However, despite these concerns, use of the spot sampling technique does represent the only currently available approach with potential as the basis of an on-farm diagnostic of MP supply.

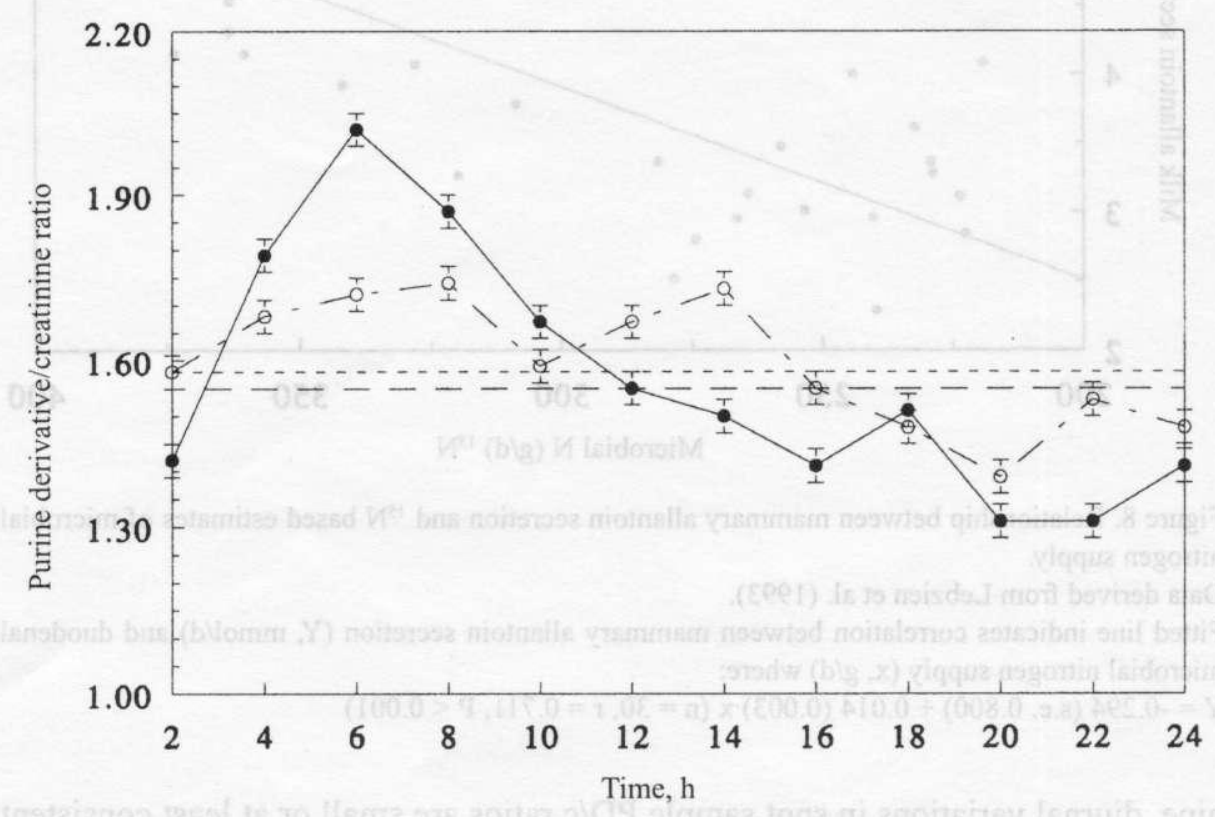

Figure 9. Diurnal variation in the molar ratio of purine derivatives to creatinine in dairy cows offered grass silage and a concentrate supplement either separately $(-\bullet)$ or as a complete diet $(-\mathrm{O}-$ ). Data derived from Shingfield and Offer (1998a). Dotted lines indicate daily mean purine derivative to creatinine ratios for separate (---) and complete diet feeding $(---)$, respectively. Each point is the mean of 24 observations with s.e. for treatment-sampling time interactions

\section{CONCLUSIONS}

Data reported in the literature has provided both direct and indirect evidence that support the validity of the assumptions of the PD technique. Estimates of rumen microbial synthesis based on urinary PD excretion are, in general, consistent with values derived using standard in vivo procedures. Difficulties in obtaining representative samples of rumen microbes and uncertainities concerning variations in non-renal excretion and endogenous purine losses, lead to the general 
conclusion that use of the PD technique is confined to the assessment of relative differences rather than absolute estimates of MP supply. Consequently, estimates based on this approach do not appear to be sufficiently reliable to be considered as reference measurements for the future development of prediction models within modern metabolisable protein evaluation systems. However, despite concerns of establishing a valid sampling protocol and therefore providing an accurate prediction of urinary PD excretion, use of the spot sampling technique does appear to have sufficient potential as an on-farm diagnostic of MP supply. In contrast, mammary PD secretion, whilst being extremely attractive duc to the ease of sampling appears to be of little value for the assessment of MP supply duc a mutual correlation with milk yicld.

\section{REFERENCES}

Agricultural and Food Research Council, 1992. Technical Committee on Responses to Nutrients, Report number 9. Nutritive Requirements of Ruminant Animals: Protein. Nutr. Abstr. Rev., Ser. B $62,788-835$

Agricultural Reseach Council, 1984. The Nutrient Requirements of Ruminant Livestock. Suppl. 1, Commonwealth Agricultural Bureaux. Farningham Royal. Slough

Ahvenjärvi S., Vanhatalo A., Huhtanen P., Varvikko T., 1999. Effects of supplementation of a grass silage and barley diet with urea, rapeseed meal and heat-moisture-treated rapeseed cake on omasal digesla flow and milk production in lactating dairy cows. Acta. Agr. Scand., Sect. A, Anim. Sci. 49, 179-189

Al-Khalidi U.A.S.. Chaglassian T.H., 1965. The species distribution of xanthine oxidase. Biochem. J. $97.318-320$

Allam Von S.M.. Rohr K., Brandt M., Lebzien P., 1982. Quantification of N-metabolism in the forestomachs of dairy cows. 3. Diaminopimelic acid and ${ }^{15} \mathrm{~N}$ as markers for microbial nitrogen in duodenal digesta (in German). Z. Tierphysiol., Tierernähr., Futtermittelk. 48, 58-64

Antoniewic\% A., 1983. Urinary allantoin as an indicator of rumen development in lambs. Roc\%. Nauk. Zoot. 10, 181-190

Antoniewicz A.. Heinemann W.W., Hanks E.M., 1980. The effect of changes in the intestinal flow of nucleic acids on allantoin excretion in the urine of sheep. J. Agr. Sci. 95, 395-400

Antonicwic7. A., Pisulewski P.M., 1982. Measurement of endogenous allantoin excretion in sheep urine. J. Agr. Sci. 98, 221-223

Arambel J.M., Bartley E.E., Dufva G.S., Nagaraja T.G., Dayton A.G., 1982. Effect of diet on amino acid and nucleic acids of rumen bacteria and protozoa. J. Dairy Sci. 65, 2095-2101

Baicells J.. Fondevilla M., Guada J.A., Castrillo C., Surra J.C.E.. 1993. Urinary excretions of purine derivatives and nitrogen in sheep given straw supplemented with different sources of carbohydrates. Anim. Prod. 57, 287-292

Baicells J.. Guada J.A. Castrillo C.. Gasa J.. 1991. Utinary excretion of allantoin and allantoin precursors by sheep after different rates of purine infusion into the duodenum. J. Agr. Sci. 116 , 309-317

Balcells J., Parker D.S., Seal C.J., 1992. Purine metabolite concentrations in portal and peripheral blood of stecrs, sheep and rats. Comp. Biochem. Physiol. 10! B, 633-636 
Barman T.E., 1969. Enzyme Handbook. Springer-Verlag, New York

Barnard E.A., 1969. Biological function of pancreatic ribonuclease. Nature 221, 340-344

Bates D.B., Bergen W.G., 1984. Elfect of nutricnt limitation on the RNA/protein ratio of several bacteria. Can. J. Anim. Sci. 64, Suppl. 1. 45-46

Bates D.B., Gillet J.A., Barao S.A., Beren W.G., 1985. The elfect of specific growth rate and stage of growth on nucleic acid-protein values of pure cultures and mixed rumen bacteria. J. Anim. Sci. $61,713-724$

Beckers Y., Thewis A., 1994. Excretion of purine derivatives in urine of Belgium Blue bulls following duodenal infusion of purines from Torula Yeast. In: D. Giesecke (Editor). Proceedings of the Society of Nutrition Physiology, Vol. 3. DLG-Verlag, Frankfurt, p. 235

Belasco I.J., 1954. New nitrogen feed compounds for ruminants - A laboratory evaluation. J. Anim. Sci. 13, 601-610

Bergen W.G., Bates D.B., Johnson D.E., Waller J.C., Black J.R., 1982. Rumen microbial protein synthesis and efficiency. In: F.N. Owens (Editor). Proceedings of an International Symposium on Protein Requirements for Cattle. Oklahoma State University, Stillwater, OK, pp. 99- 112

Berlin R.D., Hawkins R.A., 1968. Secretion of purines by the smal! intestine: general characteristics. Amer. J. Physiol. 215, 932-941

Broderick G.A., Clayton M.K., 1997. A statistical evaluation of animal and nutritional factors intlucncing concentrations of milk urea nitrogen. J. Dairy Sci. 80, 2964-2971

Broderick G.A., Merchen N.R., 1992. Markers for quantifying microbial protein synthesis in the rumen. J. Dairy Sci. 75, 2618-2632

Burridge P.W., Woods R.A., Henderson J.F.. 1976. Utilisation of dietary nucleic acid purines for nucleotide and nucleic acid synthesis in the mouse. Can. J. Biochem. 54, 500-506

Calsamiglia S., Stern M.D., Firkins J.L., 1996. Comparison of nitrogen-15 and purines as microbial markers in continuous culture. J. Anim. Sci. 74, 1375-1381

Carro M.D., Valdés C., Ranilla M.J., González J.S., 2000. Elfect of forage to concentrate ratio in the diet on ruminal fermentation and digesta flow kinetics in sheep offered food at a fixed and restricted level of intake. Anim. Sci. 70, 127-134

Cecava M.J., Merchen N.R., Berger L.L., Mackie R.I., Fahey G.C., 1991. Effects of dietary energy level and protein source on nutrient digestion and ruminal nitrogen metabolism in steers. J. Anim. Sci. 69, 2230-2243

Cecava M.J., Merchen N.R., Gay L.C., Berger L.L., 1990. Composition of ruminal bacteria harvested from steers as influenced by dietary energy level, feeding frequency, and isolation techniques. J. Dairy Sci. 73, 2480-2488

Chamberlain D.G., Choung J.J., 1995. The importance of rate of ruminal fermentation of energy sources in diets for dairy cows. In: P.C. Garnsworthy, D.J.A. Cole (Editors). Recent Advances in Animal Nutrition. Nottingham University Press, Nottingham, pp. 3-27

Chen X.B., Chen Y.K., Franklin M.F., Ørskov E.R., Shand W.K., 1992a. The effect of feed intake and body weight on purine derivative excretion and microbial protein supply. J. Anim. Sci. 70 , 1534-1542

Chen X.B., Chowdhury S.A., Hovell F.D.De.B, Ørskov E.R, Kyle D.J., 1992b. Endogenous allantoin cxcretion in response to changes in protein supply in sheep. J. Nutr. 122, 2226-2232

Chen X.B., Fujihara T., Nakamura K., Mawuenyegah P.O., Franklin M.F., Kylc D.J., 1997. Response of urinary and plasma purine derivatives to various rates and infusion patterns of purines in sheep nourished by intragastric infusion. J. Agr. Sci. 129, 343-352

Chen X.B., Grubic G. Ørskov E.R., Osuji P., 1992c. Effect of feeding frequency on diumal variation in plasma and urinary purine derivatives in steers. Anim. Prod. 55, 185-191 
Chen X.B., Hovell F.D.DeB., Ørskov E.R., Brown D.S., 1990a. Excretion of purine derivatives by ruminants: effect of exogenous nucleic acid supply on purine derivative excretion by sheep. Brit. J. Nutr. 63, 131-142

Chen X.B., Hovell F.D.DeB.. Ørskov E.R., 1990b. Excretion of purine derivatives by ruminants: recycling of allantoin into the rumen via saliva and its fate in the gut. Brit. J. Nutr. 63, 197-205

Chen X.B., Kyle D.J., Ørskov E.R., Hovell F.D.DeB., 1991. Renal clearance of plasma allantoin in sheep. Exp. Physiol. 76, 59-65

Chen X.B., Mejia A.T., Kyle D.J., Orskov E.R., 1995. Evaluation of the use of the purinc derivative:creatinine ratio in spol urine and plasma samples as an index of microbial protein supply in ruminants: studies in sheep. J. Agr. Sci. 125, 137-143

Chen X.B., Ørskov E.R., Hovell F.D.DeB., 1990c. Excretion of purine derivatives by ruminants: endogenous cxcretion, differences between cattle and sheep. Brit. J. Nutr. 63, 121 129

Clark J.H., Klusmeyer T.H., Cameron M.R., 1992. Microbial protein synthesis and flows of nitrogen fractions and amino acid nutrition in dairy cattle. J. Dairy Sci. 75, 2304-2323

Cockburn J.E., Williams A.P., 1984. The simultaneous estimation of the amounts of protozoal, bacterial and dietary nitrogen entering the duodenum of steers. Brit. J. Nutr. 51, 111-132

Condon R.J., Hall G., Hatfield E.E., 1970. Metabolism of abomasally intused ${ }^{\text {H_C }}$ labelled RNA, adenine, uracil and glycine. J. Anim. Sci. 31, 1037-1038 (Abstr.)

Condon R.J., Hatfield E.E., 1970. Metabolism of abomasally infused ribonucleic acid by sheep J. Anim. Sci. 31, 1037 (Abstr.)

Coto G., Ortiz F., Cruz R., Lopez F., 1984. Determination of allantoin in urine for estimating the microbial mass synthesis in the rumen. Cuban J. Agr. Sci. 18, 43-49

Craig W.M., Broderick G.A., Ricker D.B. 1987a. Quantitation of microorganisms associated with the particulate phase of rumen ingesta. J. Nutr. 117, 56-62

Craig W.M., Brown D.R., Broderick G.A., Ricker D.B., 1987b. Post-prandial compositional changes of thid and particle associated ruminal micro-organisms. J. Anim. Sci. 65, 1042 1048

Czerkawski J.W., 1976. Chemical composition of microbial matter in the rumen. J. Sci. Food Agr. 27, 621-632

Daniels Z.M., Chen X.B., Kyle D.J., Sinclair K., Ørskov E.R., 1994. Purine derivatives in urine and plasma of lactating cows given different leveis of feed intake. Anim. Prod. 58, 453 (Abstr.)

Dapoza C., Castrillo C., Balcells J., Martín-Orúe S., Guada J.A., 1999. On the variation of urinary excretion of creatinine and purine derivatives in pregnant and lactating ewes given diets with difterent protein contents. Anim. Sci. 68, 555-566

Dawson J.M., Bruce C.I., Buttery P.J., Gill M.. Beever D.E., 1988. Protein melabolism in the rumen of silage-fed steers: effect of fishmeal supplementation. Brit. J. Nutr. 60. 339-353

De Groot T.H., Aaljes J.H., 1960. On the constancy of creatinine excretion in the urine of the dairy cow. Brit. Vet. J. 116. 409-418

Deutsch A., Mattsson S., 1959. Purine and pyrimidine derivatives in cows' milk. Filieenth International Dairy Congress, Vol. 3. pp. 1700-1703

Dewhurst R.J.. Hepper D., Webster A.J.F., 1995. Comparison of in sacco and in vitro techniques for estimating the rate and extent of rumen fermentation of a range of dietary ingredients. Anim. Feed Sci. Tech. 51, 211-229

Dewhurst R.J., Mitton A.M., Offer N.W., Thomas C., 1996. Effects of the composition of grass silages on milk production and nitrogen utilisation by dairy cows. Anim. Sci. 62, 25-34 
Dewhurst R.J., Webster A.J.F., 1992. Effect of diet, level of intake. sodium bicarbonate and monesin on urinary allantoin excretion in sheep. Brit. J. Nutr. 67, 345-353

Djouvinov D.S., Todorov N.A., 1994. Influence of dry matter intake and passage rate on microbial protein synthesis in the rumen of sheep and its cstimation by cannulation and a non-invasive method. Anim. Feed Sci. Tech. 48, 289-304

D'Mello J.P.F., 1982. Utilisation of dietary purines and pyrimidines by non-ruminant animals. Proc. Nutr. Soc. 41, 301-308

Dufva G.S., Bartley E.E., Arambel M.J., Nagaraja T.G., Dennis S.M., Galitzer S.J., Dayton A.D., 1982. Diaminopimelic acid content of feeds and rumen bacteria and its usefulness as a rumen bacterial marker. J. Dairy Sci. 65, 1754-1759

Ellis W.C.. Bleichner K.C., 1969a. Apparent utilisation of absorbed purines by sheep. J. Anim. Sci. 29, 157 (Abstr.)

Ellis W.C.. Bleichner K.C., 1969b. Synthesis and digestion of nucleic acids in the gastro-intestinal tract of sheep. Fed. Proc. 28. 623 (Abstr.)

Erb R.E., Surve A.H.. Randal R.D., Carverick H.A., 1977. Urinary creatinine as an index of urinary excretion of estrogen in cows prepartum and postpartum. J. Dairy Sci. 60, 825-828

Faichney G.J., Poncet C., Lassalas B., Jouany J.P.. Millet L.. Doré J., Brownlee A.G., 1997. Effect of concentrates in a hay diet on the contribution of anaerobic fungi, protozoa and bacteria to nitrogen in rumen and duodenal digesta in sheep. Anim. Feed Sci. Tech. 64, 193-213

Faichney G.J., Welch R.J., 1994. Renal excretion of allantoin and creatinine by Merino sheep selected for higher clean fleece weight. In: D. Giesecke (Editor). Proceedings of the Society of Nutrition Physiology, Vol. 3. DLG-Vcrlag, Frankfurt, p. 113

Faichney G.J., Welch R.J., Brown G.H., 1995. Prediction of the excretion of allantoin and total purine derivatives by sheep from the 'crcatinine cocfficient'. J. Agr. Sci. 125, 425-428

Ferguson J.D., Chalupa W., 1989. Symposium: Interactions of nutrition and reproduction. Impact of protein nutrition on reproduction in dairy cows. J. Dairy Sci. 72, 746-766

Ferguson W.S., Terry R.A., 1953. Purines in grassland herbage. Nature 172, 346-347

Firkins J.L.. Berger L.L., Merchens N.R., Fahey G.C., Mulvaney R.L., 1987. Ruminal nitrogen metabolism in steers as affected by feed intake and dietary urea concentration. J. Dairy Sci. 70, 2302-2311

Fox I.H., 1978. Degradation of purine nucleotides. In: W.N. Keliey. I.M. Weiner (Editors). Uric Acid-Handbook of Experimental Pharmocology. Springer-Verlag, Berlin, pp. 93-116

Fujihara T., Ørskov E.R., Reeds P.J., Kyle D.J., 1987. The effect of protein infusion on urinary excretion ol purine derivatives in ruminants nourished by intragastric nutrition. J. Agr. Sci. 109, 7-12

Giesecke D., Balslicmke J., Südekum K.H., Stangassinger M., 1993. Plasma level, clearance and renal excretion of endogenous and ruminal purines in the bovine (in German). J. Anim. Physiol. Anim. Nutr. 70, 180-189

Giesecke D., Ehrentreich L.. Stangassinger M., Ahrens F., 1994. Mammary and renal excretion of purine melabolites in relation to energy intake and milk yield in dairy cows. J. Dairy Sci. 77 , 2376-2381

Giesecke D.. Stangassinger M., Tiermeyer W., 1984. Nucleic acid digestion and urinary purine metabolites in sheep nourished by intragastric infusions. Can. J. Anim. Sci. 64, Suppl. 1, 144-145 (Abstr.)

Gonda H.L., Lindberg J.E., 1994. Evaluation of dictary nitrogen utilisation in dairy cows based on urea concentrations in blood, urine and milk, and on urinary concentrations of purine derivatives. Acta. Agr. Scand., Sect. A, Anim. Sci. 44, 236-245

Gonda H.L., Lindberg J.E., 1997. Effect of diet on milk allantoin and its relationship with urinary allantoin in dairy cows. J. Dairy Sci. 80, 364-373 
Gots J.S., 1971. Regulation of purine and pyrimidine metabolism. In: H.J. Vogel (Editor). Metabolic Regulation. Vol. 5. Academic Press, London, pp. 225-255

Greger R. Lang F., Deetjen P., 1976. Renal excretion of purine metabolites, urate and allantoin, by the mammalian kidney. In: K. Thurau (Editor). International Review of Physiology. Kidney and Urinary Tract Physiology. Vol. 2, pp. 257-281

Harrison D.G., Beever D.E.. Osbourne D.F.. 1979. The contribution of protozoa entering the duodenum of sheep. Brit. J. Nutr. 41, 521-527

Hartman S.C., 1970. Purines and pyrimidines. In: D.M. Greenberg (Editor). Metabolic Pathways. Vol. 4. Academic Press, London, pp. 1-58

Henderson J.F., Paterson A.R.P., 1973. Nucleotide Metabolism: An Introduction. Academic Press, London

Hitchings G.H., 1978. Uric acid: chemistry and synthesis. In: W.N. Kelley, I.M. Weiner (Editors). Uric Acid-Handbook of Experimental Pharmocology. Springer-Verlag, Berlin, pp. 1-20

Hoover W.H., Stokes S.R., 1991. Balancing carbohydrates and proteins for optimium rumen microbial yield. J. Dairy Sci. 74, 3630-3644

Horigane A., Horiguchi M., 1990. Nutritional aspects and metabolism of aminophosphonic acids in ruminants. In: S. Hoshino, R. Onodera, H. Minato, H. Itabashi (Editors). The Rumen Ecosystem. The Microbial Metabolism and its Regulation. Springer-Verlag, New York. pp. 51 -59

Huhtanen P.. Miettinen H.. Toivonen V., 1997. Effects of silage fermentation and post-ruminal cascin supplementation in lactating dairy cows: 1. Diet digestion and milk production. J. Sci. Food Agr. 74, 450-458

Huhtanen P., Vanhatalo A., Varvikko T., 1998. Enzyme activities of rumen particles and feed samples incubated in situ with differing types of cloth. Brit. J. Nutr. 79, 161-168

Jackson T.C., Schelling G.T., Mitchell G.E., Tucker R.E., 1976. Nucleic acid bases in sheep digesta. J. Anim. Sci. 43, 437 (Abstr.)

John A., 1984. Effects of fecding frequency and level of feed intake on chemical composition of rumen bacteria. J. Agr. Sci. 102, 45-57

John A., Ulyatt M.J., 1984. Measurement of protozoa, using phosphatidyl choline, and of bacteria, using nucicic acid, in the duodenal digesta of sheep fed chaffed lucerne hay (Medicago sativa L.) diets. J. Agr. Sci. 102, 33-44

Johnson L.M., Harrison J.H., Riley R.E.. 1998. Estimation of the flow of microbial nitrogen to the duodenum using uric acid or allantoin. J. Dairy Sci. 81, 2408-2420

Jurtshuk P., Doetsch R.N., Shaw J.C., 1958. Anaerobic purine dissimilation by washed suspensions of bovine rumen bacteria. J. Dairy Res. 41, 190-202

Kahn L.P., Nolan J.V., 1993. Prediction of microbial yicld from the rumen using urinary excretion of purine derivatives and studies of the kinetics of labelled purines. In: Feeding Statergies for Improving Ruminant Productivity in Areas of Fluctuating Nutrient Supply. IAEA, Vicnna, pp. $109-121$

Kanjanapruthipong J., Leng R.A., 1998. Purine derivatives in urine as an indicator estimating microbial yicld from the rumen: A-Review. Asian-Austr. J. Anim. Sci. 11, 209-216

Kay R.N.B.. 1966. The influence of saiiva on digestion in ruminants. World Rev. Nutr. Dietetics 6 , 292-325

Kirchgessner M., Kreuzer M., 1985. Urea and allantoin in the milk of cows during and after feeding protein in excess or protein deficiency 5 . The influence of incorrecl protein nutrition of lactating cows and its residual effects (in German). J. Anim. Physiol. Anim. Nutr. 54, 141-151

Kirchgessner M., Windisch W., 1989. Milk urea content and allantoin excretion of cows during and after energy and protein depletion. Part 4 . The influence of energy and protein depletion and its residual effects (in German). J. Anim. Physiol. Anim. Nutr. 62, 113-118 
Klusmeyer T.H., Ohl M.W., Clark J.H., 1991. Effects of using particle-associated bacteria (PAB), fluid associated bacteria (FAB) or mixed rumen bacteria $(\mathrm{MB})$ for calculating nutrient flow to the duodenum of dairy cows. J. Dairy Sci. 74, Suppl. 1, 248 (Abstr.)

Laurent F., Vignon B., 1983. Factors of variation in urinary excretion of allantoin in sheep and goats (in German). Arch. Anim. Nutr, 33, 671-681

Lebzien V.P., Giesecke D., Wiesmayr S., Rohr K., 1993. Measurement of microbial protein synthesis in the rumen of cows by ${ }^{15} \mathrm{~N}$ determination in duodenal contents and excretion of allantoin in the milk (in German), J. Anim. Physiol. Anim. Nutr, 70, 82-88

Legay-Carmier F., Bauchart D., 1989. Distribution of bacteria in the rumen contents of dairy cows given a diet supplemented with soya-bean oil. Brit. J. Nutr. 61, 725-740

Lehninger A.L., 1982. Biochemistry: The Molecular Basis Cell Structure and Function. 2nd Edition, Worth Publishers

Leleiko N.S., Bronstein A., Munro H.N., 1979. Etfect of dietary purines on de-novo synthesis of purine nucleotides in the small intestinal mucosa. Pediat. Res. 13, 403 (Abstr.)

Lindberg J.E., 1985. Urinary allantoin excretion and DOM intake in dairy goats. Swedish J. Agr. Res. 15, 31-37

Lindberg J.E., 1989. Nitrogen metabolism and urinary excretion of purines in goat kids. Brit. J. Nutr. 61, 309-321

Lindberg J.E., 1991. Nitrogen and purine metabolism in preruminant and ruminant goat kids given increasing amounts of ribonucleic acids. Anim. Feed Sci. Tech. 35, 213-226

Lindberg J.E., Bristav H., Manyenga A.R., 1989. Excretion of purines in the urine of sheep in relation to duodenal flow of microbial protein. Swedish J. Agr. Res. 19, 45-52

Lindberg J.E., Jacobsson K.G., 1990. Nitrogen and purine metabolism at varying energy and protein supplies in sheep sustained on intragastric infusion. Brit. J. Nutr. 64, 359-370

Ling J.R., Buttery P.J., 1978. The simultaneous use of ribonucleic acid. ${ }^{35} \mathrm{~S}, 2$,6-diaminopimelic acid and 2-aminoethylphosphonic acid as markers of microbial nitrogen entering the duodenum of sheep. Brit. J. Nutr. 39, 165-179

Madsen J., Hvelplund T., Weisbjerg M.R., Bertilsson J., Olsson I., Spörndly R., Harstad O.M., Volden H., Tuori M., Varvikko T., Huhtanen P., Olafsson B.L., 1995. The AAT/PBV Protein Evaluation System for Ruminants. A revision. Norwegian J. Agr. Sci., Suppl. No. 19, pp. 37

Makkar H.P.S., Becker K., 1999. Purine quantification in digesta from ruminants by spectrophotometric and HPIC methods. Brit. J. Nutr. 81, 107-112

Martin C., Williams A.G., Michel-Doreau B., 1994. Isolation and characteristics of the protozoa and bacterial fractions from bovine ruminal contents. J. Anim. Sci. 72, 2962-2968

Martín-Orúc S.M., Balcells J., Zakraoui F., Castrillo C.. 1998. Quantification and chemical composition of mixed bacteria harvested from solid fractions of rumen digesta: effect of detachment procedure. Anim. Feed Sci. Tech. 71, 269-282

Martín-Orúc S.M., Dapoza C., Balcells J., Castrillo C., 1996. Purine derivatives excretion in lactating ewes fed straw diets with different levels of fïh meal. Anim. Feed Sci. Tech. 63, $341-346$

Matsumoto M.. Itabashi H.. 1988. Increased urinary excretion of allantoin in pre-ruminant kids caused by yeast ingestion. Jpn. J. Zootech. Sci. 59, 395-401

McAllan A.B., 1980. The degradation of nucleic acids in, and the removal of breakdown products from the small intestine of steers. Brit. J. Nutr. 44, 99-112

McAllan A.B., 1982. The fate of nucleic acids in ruminants. Proc. Nutr. Soc. 41, 309-317

McAllan A.B., Cockburn J.E., Williams A.P., Smith R.H., 1988. The degradation of different protein supplements in the rumen of steers and the effects of these supplements on carbohydrate digestion. Brit. J. Nutr. 60, 669-682 
McAllan A.B., Smith R.H., 1973a. Degradation of nucleic acids in the rumen. Brit. J. Nutr. 29 , $331-345$

McAllan A.B., Smith R.H., 1973b. Degradation of nucleic acid derivatives by rumen bacteria in vitro. Brit. J. Nutr. 29, 467-474

McAllan A.B., Smith R.H., 1984. The efficiency of microbial protein synthesis in the rumen and the degradability of feed nitrogen between the mouth and abomasum in steers given different diets. Brit. J. Nutr. 51, 77-83

Merry R.J., McAllan A.B., 1983. A comparison of the chemical composition of mixed bacteria harvested from the liquid and solid fractions of rumen digesta. Brit. J. Nutr. 50, 701-709

Michalct-Doreau B., Ould-Bah M.Y., 1992. In vitro and in situ methods for the estimation of dietary nitrogen degradability in the rumen: a review. Anim. Feed Sci. Tech. 40, 57-86

Morris S., Ray S.C., 1939. The fasting metabolism of ruminants. Biochem. J. 33, 1217-1230

Motojima K., Goto S., 1990. Characteristics of liver-specific expression of rat uricase using monoclonal antibodies and cloned cDNAs. Biochim. Biophys. Acta 1087, 316

Mugdal V.D., Taneja V.K., 1977. Synthesis of nucleic acid in buffalo under different levels of dietary nitrogen. Indian J. Anim. Sci. 47, 709-714

Mudgal V.D., Taneja V.K., Wallis T.K., 1978. Some studies on nucleic acid and incorporation of "s in the microbial protein synthesis in buffalo rumen. J. Nucl. Agr. Biol. 7, 102-107

Mura U., Osman A.M., Mohammed A.S., Martino D.D., lpata P.L., 1987. Purine salvage as metabolite and energy saving mechanism in Camelus dromedarius: The recovery of guanine. Comp. Biochem. Physiol. 1, 157-160

Murray A.W., 1971. The biological significance of purine salvage. Annu. Rev. Biochem. 40, 811-826

National Reseach Council, 1989. Nutrient Requirements of Dairy Cattle. 6th Edition. Natl. Acad. Press, Washington, DC

Nocek J.E., 1988. In situ and other methods to estimate ruminal protein and energy digestibility: a review. J. Dairy Sci. 71, 2051-2069

Obispo N.E., Dehority B.A., 1999. Feasibility of using total purines as a marker for ruminal bacteria. J. Anim. Sci. 77, 3084-3095

Oldham J.D.. 1984. Protein-energy interrelationships in dairy cows. J. Dairy Sci. 67, 1090-1114

Olubobokun J.A., Craig W.M., 1990. Quantity and characteristics of microorganisms associated with ruminal fluid or particles. J. Anim. Sci. 68, 3360-3370

Olubobokun J.A., Craig W.M., Nipper W.A., 1988. Characteristics of protozoal and bacterial fractions from microorganisms associated with ruminal fluid or particles. J. Anim. Sci. 66, 2701-2710

Pérez J.F., Balcells J., Fondevila M., Guada J.A., 1998. Composition of liquid- and particle associated bacteria and their contribution to the rumen outflow. Aust. J. Agr. Res. 49, 907-914

Pérez J.F., Balcells J., Guada J.A., Castrillo C., 1996a. Determination of rumen nitrogen production in sheep: a comparison of urinary purine derivative excretion with methods using ${ }^{15} \mathrm{~N}$ and purine bases as markers of microbial-nitrogen entering the duodenum. Brit. J. Nutr. 75, 699-709

Pérez J.F., Balcells J., Guada J.A., Castrillo C., 1997. Rumen microbial production estimated either from urinary purine derivative excretion or from direct measurements of ${ }^{15} \mathrm{~N}$ and purine bases as microbial markers: effect of protein source and rumen bacteria isolates. Anim. Sci. $65,225-236$

Pérez, J.F., Rodriguez. C.A., Gonzalez. J., Balcells J., Guada J.A., 1996b. Contribution of dictary purine bases to duodena! digesta in sheep. In situ studies of purine degradability corrected for microbial contamination. Anim. Feed Sci. Tech. 62, 251-262

Puchala R., Kulasck G.W., 1992. Estimation of microbial protein from the rumen of sheep using microbial nucleic acid and urinary excretion of purine derivatives. Can. J. Anim. Sci. 72, 821-830 
Puchala R., Shelford J.A., Barej W., Kulasek G.W., Pior H., Keyscrlingk M.V., Makoni N., 1993. Urinary excretion of pseudouridine and purine metabolites in ruminants. J. Anim. Physiol. Anim. Nutr. 69, 186-193

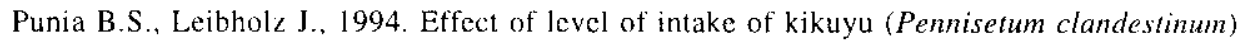
grass hay on the flow of protozoal nitrogen to the omasum of cattle. Anim Feed Sci. Tech. $47,77-87$

Punia B.S., Lcibholz J., Faichney G.J., 1988. Effects of level of intake and urea supplementation of alkail-treated straw on protozoal and bacterial nitrogen synthesis in the rumen and partition of digestion in cattle. Aust. J. Agr. Res. 39.1181-1194

Punia B.S., Leibholz J., Faichney G.J., 1992. Rate of production of protozoa in the rumen and the flow of protozoal nitrogen to the duodenum in sheep and cattle given a pelleted diet of lucerne hay and barley. J. Agr. Sci. 118, 229-236

Rahnema S.H.. Theurer B.. 1986. Comparison of various amino acids for estimation of microbial nitrogen in digesta. J. Anim. Sci. 63, 603-612

Razzaque M.A., Topps J.H., Kay R.N.B.. Brockway J.M., 1981. Metabolism of the nucleic acids of rumen bacteria by preruminant and ruminant lambs. Brit. J. Nutr. 45, 517-527

Rinne M., Jaakkola S., Kaustell K., Heikkilä T., Huhtanen P., 1999. Silages harvested at different stages of grass growth v. concentrate foods as energy and protein sources in milk production. Anim. Sci. 69, 251-263

Robinson P.H., Fadel J.G., Ivan M.. 1996. Critical evaluation of diaminopimelic acid and ribonucleic acid as markers to estimate rumen pools and duodenal flows of bacterial and protozoal nitrogen. Can. J. Anim. Sci. 76, 587-597

Robinson P.H., Sniffen C.J., van Soest P.J., 1985. Influence of level of feed intake on digestion and bacterial yield in the forestomachs of dairy cattle. Can. J. Anim. Sci. 65, 437-444

Rosskopf R., Rainer H., Giesecke D., 1991. Purine and pyrimidine metabolites for the evaluation of rumen metabolism: HPLC analysis in milk and blood plasma (in German). Arch. Anim. Nutr. $41,411-426$

Roussos G.G., 1963. Studies on a hypoxanthine oxidase from the bovine small intestine. Biochem. Biophys. Acta 73, 338-340

Ryś R., Antoniewicz A., Kryściak J., Maciejewicz J., Walicka E., 1973. Conversion of food protein into microbial protein in the rumen. 2. Allantoin in urine as index of conversion. Rocz. Nauk. Zoot. 95, 89-95

Ryś R., Antoniewicz A., Maciejewicz J., 1975. Allantoin in urine as an index of microbial protein in the rumen. In: Tracer Studies on Non-Protein Nitrogen for Ruminants. Vienna International Atomic Agency, pp. 5-98

Sadik M.S., Huber J.T., King K., Wanderley R., DeYoung D., Al-Dehneh A., Dudas C., 1990. Comparison of nitrogen-15 and diaminopimelic acid for estimating bacterial protein synthesis of lactating cows fed diets of varying protein degradability. J. Dairy Sci. 73, 694-702

Satter L.D., 1986. Protein supply from undegraded dietary protein. J. Dairy Sci. 69, 2734-2749

Savaiano D.A., Ho C.Y., Chu V.. Clifford A.J., 1980. Metabolism of orally and intravenously administered purines in rats. J. Nutr. 110, 1793-1804

Schelling G.T., Byers F.M., 1984. Cytosine as a marker for microbial nitrogen leaving the rumen. Can. J. Anim. Sci. 64, Suppl. 1, 52-53 (Abstr.)

Schelling G.T., Koenig S.E., Jackson T.C., 1982. Nucleic acid bases and purine or pyrimidine bases as markers for protein synthesis in the rumen. In: F.N. Owens (Editor). Proceedings of an International Symposium on Protein Requirements for Cattle. Oklahoma State University, Stillwater, OK. pp. 1-9 
Schönhusen U., Voigt J., Kreienbring F., Teuscher F., 1995. Evaluation of different markers for the determination of the microbial nitrogen flow into the duodenum of dairy cows (in German). Arch. Anim. Nutr. 48, 147-158

Schönhusen U., Voigt J., Lammers-Weinhoven, S.C.W., Van Bruchem J., 1999. Passage of ribonucleic acid along the intestine of sheep. Arch. Anim. Nutr. 52, 335-349

Scott J.L.. 1962. Human leukocyte metabolism in-vitro. I. incorporation of adenine-8 ${ }^{1+} \mathrm{C}$ and formate- ${ }^{14} \mathrm{C}$ into the nucleic acids of leukemic leukocytes. J. Clin. Invest. 41,67-79

Shingfield K.J., Offer N.W., 1998a. Evaluation of the spot urine sampling technique to assess urinary purine derivative excretion in lactating dairy cows. Anim. Sci. 66, 557-568

Shingfield K.J., Offer N.W., 1998b. Evaluation of milk allantoin excretion as an index of microbial protein supply in dairy cows. Anim. Sci. 67, $371-385$

Shingfield K.J., Offer N.W., 1999a. Simultancous determination of purine metabolites, creatinine and pseudouridine in ruminant urine by reversed-phase high-performance liquid chromatography. J. Chromatogr. B. 723, 81-94

Shingfield K.J.. Offer N.W., 1999b. Urinary psuedouridine excretion in lactating dairy cows. J. Anim. Physiol. Anim. Nutr. 82, 125-134

Sibanda S.. Topps J.H., Storm E., Ørskov E.R., 1982. The excretion of allantoin by ruminants in relation 10 protein entering the abomasum. Proc. Nutr. Soc. 4I, 75 (Abstr.)

Siddons R.C., Beever D.E., Nolan J.V., 1982. A comparison of methods for the estimation of microbial nitrogen in duodenal digesta of sheep. Brit. J. Nutr. 48, 377-389

Simmonds H.A., Rising T.J., Cadenhead A., Hatfield P.J., Jones A.S., Cameron J.S., 1973. Radioisotope studics of guanine and allopurinol in the pig. Biochem. Pharmacol. 22, 2553-2563

Smellie R.M.S., Thomson R.Y., Davidson J.N., 1958. The nucleic acid metabolism of animal cells in-vitro. I: The incorporation of ${ }^{14} \mathrm{C}$ lormate. Biochem. Biophys. Acta 29, 59-74

Smith R.C., Mathur C.F., 1973. Incorporation of adenine and uracil into nucleic acids of Streptococcus bovis. Can. J. Microbiol, 19, 591-595

Smith R.C.. Moussa N.M., Hawkins G.E., 1974. Utilisation of nucleic acids of E. coli and rumen bacteria by shecp. Brit. J. Nutr. 32, 529-537

Smith R.H., McAllan A.B.. 1970. Nucleic acid and metabolism in the ruminant. 2. Formation of microbial nucleic acid in the rumen in relation to the digestion of food nitrogen, and the fate of nucleic acids. Brit. J. Nutr. 24, 545-556

Smith R.H., McAllan A.B., 1971. Nucleic acid and metabolism in the ruminant. 3. Amounts of nucleic acid and total ammonia nitrogen in the digesta from the rumen, duodenum and ileum of calves. Brit. J. Nutr. 25, 181-190

Smith R.H., McAllan A.B., 1974. Some factors influencing the chemical composition of mixed rumen bacteria. Brit. J. Nutr. 31, 27-34

Smith R.H., McAllan A.B., Hewitt D., Lewis P.E., 1978. Estimation of amounts of microbial and dietary compounds entering the duodenum of cattle. J. Agr. Sci. 90, 557-568

Sniffen C.J., Robinson P.H., 1987. Microbial growth and flow as influenced by dietary manipulations. J. Dairy Sci. 70, 425-441

Sorensen L.B., 1960. The climination of uric acid in man. Scand. J. Clin. Lab. Invest.12, Suppl. 54, $1-214$

Sorensen L..B., 1978. Extra-renal disposal of uric acid. In: W.N. Kelley, I.M. Weiner (Editors). Uric Acid-Handbook of Experimental Pharmocology. Springer-Verlag, Berlin, pp. 325-336

Steinhour W.D., Stokes M.R., Clark J.H., Rogers J.A.. Davis C.L., Nelson D.R., 1982. Estimation of the proportion of non-ammonia-nitrogen reaching the lower gut of the ruminant derived from bacterial and protozoal nitrogen. Brit. J. Nutr. $48,4 ! 7-431$ 
Stern, M.D., 1986. Proceedings of the 1986 Cornell Nutrition Conference for Feed Manufacturers, Ithaca, NY, p. 10

Stern M.D., Hoover W.H., 1979. Methods for determining and factors affecting rumen microbial protein synthesis: a review. J. Anim. Sci. 49, 1590-1603

Stokes S.R., Hoover W.H., Miller T.K., Blauweikel R., 1991. Ruminal digestion and microbial utilization of diets varying in type of carbohydrate and protein. J. Dairy Sci. 74, 871-881

Storm E., Brown D.S., Ørskov E.R., 1983. The nutritive value of rumen micro-organisms. 3. The digestion of microbial amino and nucleic acids and losses of endogenous nitrogen from the small intestine of sheep. Brit. J. Nutr. 50, 479-485

Storm E., Ørskov E.R., 1983. The nutritive value of rumen micro-organisms. 1. Large-scale isolation and chemical composition of rumen micro-organisms. Brit. J. Nutr. 50, 463-470

Surra J.C., Guada J.A., Balcells J., Castrillo C., 1997a. Renal and salivary clearance of purine derivatives in sheep. Anim. Sci. 65, 83-91

Surra J.C., Guada J.A., Balcells J., Castrillo C., 1997b. Effects of post-ruminal fermentation on the faecal and urinary excretion of purines. Anim. Sci. 65, 383-390

Susmel P., Plazotta E., Mills C.R., Stefanon B., 1993a. Determination of RNA and ATP in the rumen liquid of cows fed with diets differing in forage to concentrate ratio. J. Sci. Food Agr. 63, 39-45

Susmel P., Spanghero M., Stefanon B., Mills C.R., 1995. Nitrogen balance and partitioning of some nitrogen catabolites in milk and urine of lactating cows. Livest. Prod. Sci. 44, 207-219

Susmel P., Spanghero M., Stefanon B., Mills C.R., Plazzotta E., 1993b. N losses, purine N derivatives excretion and intestinal digestible protein requirements of cows at maintenancc. Livest. Prod. Sci. 36, 213-222

Susmel P., Stcfanon B., Plazzotta C.R., Spanghero M., Mills C.R., 1994. The effect of energy and protein intake on the excretion of purine derivatives. J. Agr. Sci. 123, 257-265

Szumacher-Strabel M., 1998. Microbial protein net synthesis in sheep fed meadow hay supplemented with different source and level of fat. J. Anim. Feed Sci. 7, 385-394

Terroine E.F., Mourot G., 1931. L'allatoine ef les corps puriques de l'urine des mammiferes proviennent-ills partiellement de la degradation des maticres protiques? Bull. Soc. Chim. Biol. 13, 94- 109

Thomson R.Y., Ricerri G., Perotta M., 1960. The nucleic acid metabolism of animal cells in-vitro. III. Factors intluencing nucleotide biosynthesis. Biochim. Biophys. Acta 45, 87-100

Tiermeyer W., Stohrer M., Giesecke D., 1984. Metabolites of nucleic acids in bovine milk. J. Dairy Sci. $67,723-728$

Topps R.H.. Elliot R.C., 1965. Relationship between concentrations of ruminal nucleic acid and excretion of purine derivatives by sheep. Nature 205. 498-499

Tuori M., Kaustell K., Huhtanen P., 1998. Comparison of the protein evaluation systems of feeds for dairy cows. Livest. Prod. Sci. 55, 33-46

Turchinski V.V., 1980. Entry of microbial nuclcic acid into the abomasum and excretion of allantoin in sheep. Nutr. Abstr. Rev., Ser. B 51, 5866

Vagnoni D.B., Broderick G.A., 1997. Effects of supplementation of energy or ruminally undegraded protcin to lactating cows fed alfalfa hay or silage. J. Dairy Sci. 80, 1703-1712

Vagnoni D.B., Broderick G.A., Clayton M.K., Hatficld R.D., 1997. Excretion of purine derivatives by Holstein cows abomasally infused with incremental amounts of purines. J. Dairy Sci. $80,1695-1702$

Valadares R.F.D., Broderick G.A., Valadares F.S.C., Clayton M.K., 1999. Effect of replacing alfalfa silage with high moisture corn on ruminal protein synthesis estimated from excretion of total purine derivatives. J. Dairy Sci. 82, 2686-2696 
Valdés C., Carro M.D., Ranilla M.J., González J.S., 2000. Effect of forage to concentrate ratio in complete diets offered to sheep on voluntary food intake and some digestive parameters. Anim. Sci. 70, 119-126

Vanhatalo A., 1991. The digestion of domestic feeds and diets in the alimentary tract of cattle. Licenciate Thesis, University of Helsinki, pp. 153

Verbič J., Chen X.B., Macleod N.A., Ørskov E.R., 1990. Effect of microbial nucleic acids infusion on purine derivative excretion by steers. J. Agr. Sci. 114. 243-248

Vercoe J.E., 1976. Urinary allantoin excretion and digestible dry matter intake in cattle and butfalo. J. Agr. Sci. 86, 613-615

Volden H., Harstad O.M., 1998. Chemical composition of bacteria harvested from the rumen of dairy cows fed three diets differing in protein content and rumen protein degradability at two levels of intake. Acta. Agric. Scand.. Sect. A. Anim. Sci. 48, 202-209

Volden H., Mydland L.T., Harstad O.M., 1999. Chemical composition of protozoal and bacterial fractions isolated from ruminal content of dairy cows fed diets differing in nitrogen supplementation. Acta. Agric. Scand., Sect. A, Anim. Sci. 49, 235-244

Walker D.M., 1967. Nitrogen balance studies with the milk fed lamb. 6. Effect of starvation and realimentation. Brit. J. Nutr. 21, 289-308

Whitelaw F.G., Eadie M., Bruce L.A., Shand W.J., 1984. Microbial protein synthesis in cattle given roughage concentrate and all concentrate diets: the use of 2,6-diaminopimelic acid, 2-aminoethylphosphonic acid and ${ }^{35} \mathrm{~S}$ as markers. Brit. J. Nutr. 52, 249-260

Williams A.M., 1962. Nucleic acid metabolism in leukemic human leukocytes. I. In-vitro incorporation by leukocytes from chronic granulocytic leukemia. Cancer Res. 22, 314-321

Wilson H.C., Wilson D.W., 1962. Studies in-vitro of the digestion and absorption of purine ribonucleotides by the intestine. J. Biol. Chem. 237, 1643-1647

Zinn R.A., Owens F.N., 1986. A rapid procedure for purine measurement and its use for estimating net ruminal protein synthesis. Can. J. Anim. Sci. 66, 157-166 


\section{STRESZCZENIE}

\section{Określenie podaży bialka drobnoustrojów u zwierząt przeżuwających na podstawie wydalania metabolitów purynowych przez nerki i gruczol mlekowy. Referat przeglądowy}

Omówiono znaczenie wydalania metabolitów purynowych przez nerki i gruczoł mlekowy jako techniki do szacowania podaży białka pochodzenia mikrobiologicznego u przeźuwaczy. Dane podawane w literaturze zmierzają do podtrzymania słuszności założeń, że puryny przechodzące do dwunastnicy są zasadniczo pochodzenia mikrobiologicznego i że w następstwie przemian, produkty przemiany puryn (łącznic allantoina, hypoksantyna, kwas moczowy i ksantyna) są ilościowo odzyskiwane w moczu. Większość przekonywujących danych doświadczalnych sugeruje, że sekrecja metabolitów puryn w mlcku ma male znaczenie przy szacowaniu podaży białka pochodzenia mikrobiologicznego z powodu istnienia wzajemnej zależności z wydajnością mleka. W przeciwieństwie do tego, przyjęcie produktów przemiany puryn wydalanych z moczem wydaje się stanowić wskaźniki podaży białka drobnoustrojowego ogólnie zgodne $z$ wartościami otrzymanymi przy zastosowaniu standardowych metod postępowania in vivo. Dokładność tych metod zależy jednak w dużym stopniu od otrzymania reprezentatywnych prób drobnoustrojów żwacza i możliwości oceny zmienności w wydalaniu innymi - niż przez nerki “. drogami i endogennych strat puryn. Podsumowując, wydalanic produktów przemiany puryn w moczu może być wiarygodną njeinwazyjną metodą oszacowania tylko względnych różnic, raczej niż ilościowego oznaczania podaży białka pochodzenia mikrobiologicznego u zwierząt przeżuwających. 